\title{
History and Land Use Change: The New Brunswick Copper Mining and Processing Complex, Rutgers University, and Johnson \& Johnson
}

\section{By Richard L. Porter}

\section{DOI: http://dx.doi.org/10.14713/njs.v2i1.29}

\section{Abstract}

This paper is the end result of a historical study of the New Brunswick Copper Mining and Processing Complex, which was formerly sited within what is now the City of New Brunswick in Middlesex County, New Jersey. The New Brunswick Copper Mining and Processing Complex was active during the final decades of the colonial period and included both extractive and water-powered industrial components that were focused within the area bounded on the east by the Raritan River, north by Seminary Place, west by College Avenue, and south by Hamilton Street/Johnson Drive (Figure 1). This area was redeveloped during the $19^{\text {th }}$ and $20^{\text {th }}$ centuries, with the lands formerly utilized for the mining and processing of copper eventually coming to be occupied by a portion of what is now the College Avenue Campus of Rutgers University and part of the Johnson \& Johnson Worldwide Corporate Headquarters. The discovery of a mine shaft formerly associated with this early copper mining and processing complex during the demolition of a building within the Johnson \& Johnson property led to the commissioning of this study by Johnson \& Johnson. This paper provides a discussion of the history of the New Brunswick Copper Mining and Processing Complex and of the subsequent changing land uses that ultimately led to the current presence of Rutgers University and Johnson \& Johnson. Although long absent as a component of New Brunswick's cultural landscape, there remains a strong possibility that archaeological remnants of this important historic industrial site survive below ground. 
European settlement within the New Brunswick section of the Raritan River Valley began during the latter decades of the 17th century. The present City of New Brunswick traces its development as a nucleated entity to the 1680s and the establishment of a ferry serving travelers and freight utilizing the Upper Road (now Albany Street and N.J. Route 27). This ferry crossing was located very close to the present Albany Street Bridge, and early New Brunswick developed to the west of the ferry dock along Albany Street, to the south along the Burnet Street, and, to a somewhat lesser extent, to the north along the now vacated Water Street. This latter street, also known as the River Road, ran north and west along the south bank of the Raritan River to the mouth of Mile Run (just to the west of the present Landing Lane Bridge), and then continued on further westward toward the confluence of the Raritan and Millstone Rivers. The lands that would later make up the New Brunswick Copper Mining and Processing Complex were included within the extensive real property holdings on the southwest side of the Raritan that were acquired by John Inian, the owner and operator of the ferry, during the early 1680s. ${ }^{1}$

The bulk of the former Inian property was acquired by Philip French, a descendent of several prominent New York City families, circa $1732 .^{2}$ French was the son and namesake of the senior Philip French, a wealthy merchant and landowner who was active in the governments of both New York City and the colony of New York. His mother, Annetje Van Cortland Phillipse

\footnotetext{
${ }^{1}$ For additional information relative to the early history of New Brunswick see: New Brunswick and Its Industries (New Brunswick: A.E. Gordon, 1873); W. Woodford Clayton, ed., History of Union and Middlesex Counties (Philadelphia: Everts \& Peck, 1882); The City of New Brunswick: Its History, Its Homes, and Its Industries (New Brunswick: The Times Publishing Company, 1908); John P. Wall and Harold E. Pickersgill, eds., History of Middlesex County (New York: Lewis Historical Publishing Company, 1921); William H. Benedict, New Brunswick in History (New Brunswick: William H. Benedict, 1925); John P. Wall, The Chronicles of New Brunswick (New Brunswick: Thatcher-Anderson Company, 1931); and John P. Wall, "History of the Streets of New Brunswick" (manuscript, Rutgers University Libraries Special Collections and University Archives, n.d.).

${ }^{2}$ The deed detailing this transaction was apparently not recorded as it does not appear among the colonial land records held by the New Jersey State Archives or by Middlesex or Somerset Counties. A mortgage executed in 1769 stated that French acquired the property from Inian's heirs, with no date for the said transaction given; see Somerset County Mortgages (Somerset County Court House), Book A, 238.
} 


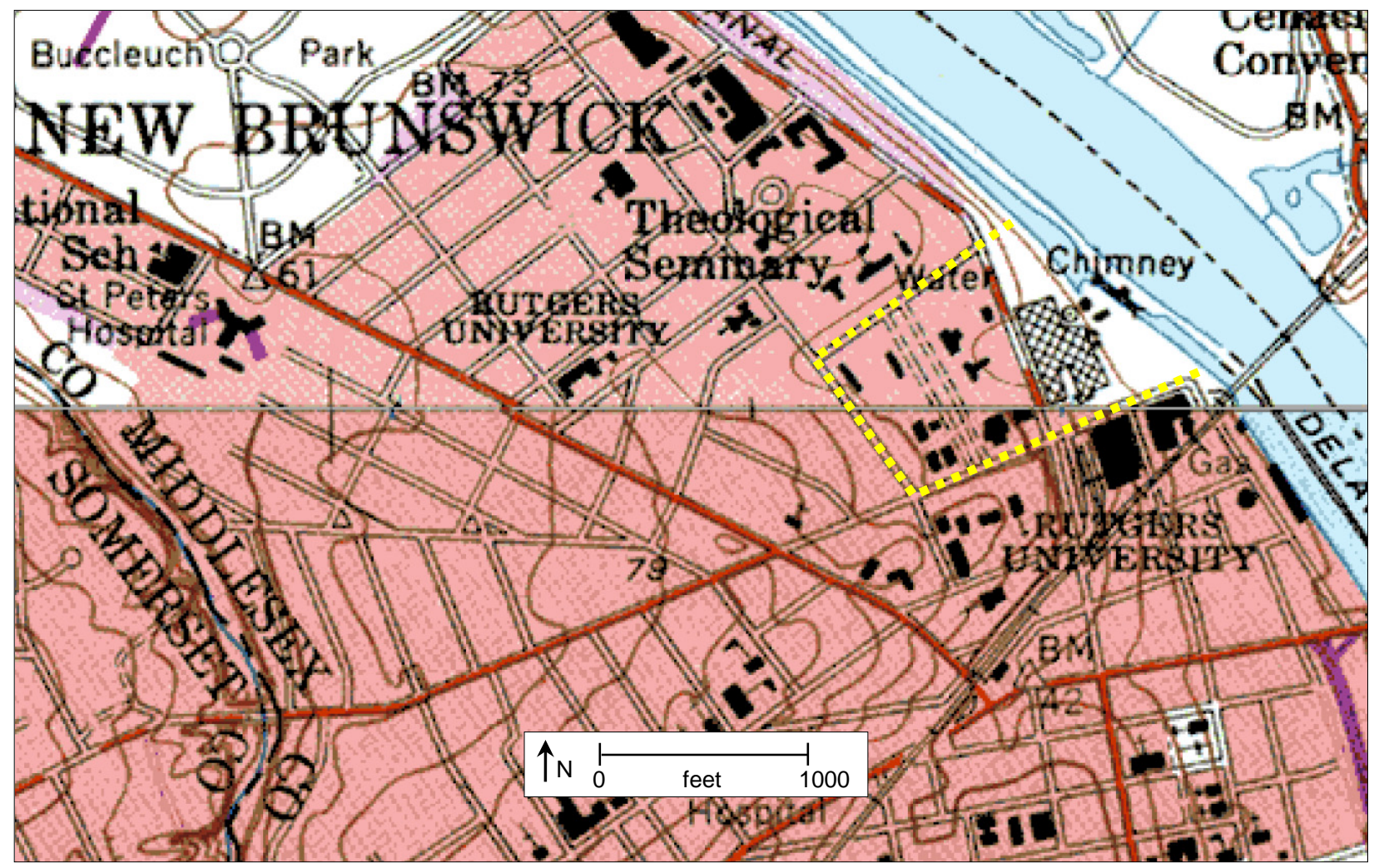

Figure 1. Location of the New Brunswick Copper Mining and Processing Complex (dashed yellow line). Source: USGS New Brunswick and Plainfield Quadrangles.

French, was the daughter of Frederick Phillipse, a merchant of Dutch descent reputed to be the wealthiest man in New York City and the owner of the Manor of Phillipsburg on the Hudson River. The younger French (1697-1782) was also a merchant in New York City prior to relocating to New Brunswick shortly after acquiring the former Inian property. French did much to promote the growth of New Brunswick as he sought to develop his real estate holdings there, but most of the town's early settlement continued to be focused along Albany and Burnet Streets. With the exception of the far southern end of Water Street, most of the area north of Albany Street, including the future site of the New Brunswick Copper Mining and Processing Complex, remained undeveloped during the colonial period. ${ }^{3}$

\footnotetext{
${ }^{3}$ William Nelson, ed., “Extracts from American Newspapers, Relating to New Jersey, Vol. 2, 1740-1750,” Documents Relating to the Colonial History of the State of New Jersey 12 (1895), 79; Benedict, New Brunswick in
} 
Philip French built his dwelling a short distance to the north of Albany Street near the present line of George Street circa 1740. This residence, which was described as one of the largest and finest houses in New Jersey, was destroyed by fire in February of $1741 .^{4}$ French is said to have immediately rebuilt, and the second "Col. French” House was shown to the north of Albany Street at the western end of New Brunswick on a map of the region produced in 1745 (Figure 2). Several other French holdings were also represented on this map, including two additional dwellings near the Upper Road's crossing of Mile Run, two more upriver at Raritan Landing, and another on the opposite side of the Raritan in what is now Highland Park. A number of other buildings were shown to be clustered at the south end of Water Street (or the River Road), which was depicted running north and west from Albany Street along the south bank of the river. It was in this year, in fact, that Water Street is said to have been properly surveyed and formally designated as a public roadway. ${ }^{5}$

In 1789 the following, credited to "a gentleman of distinction, well informed upon the subject," was published in Morse's The American Geography; or, A View of the Present Situation of the United States of America:

About the years 1748, 1749, 1750, several lumps of virgin copper from five to thirty pounds weight, (in the whole upwards of 200 pounds) were plowed up in a field, belonging to Philip French, Esq; within a quarter of a mile of New Brunswick. This induced Mr. Elias Boudinot, of the city of Philadelphia, to take a lease of Mr. French of this land, for ninety-nine years, in order to search for copper ore, a body of which he concluded must be contained in this hill. ${ }^{6}$

History, 25, 31-2, 55, 255-6; Wall, The Chronicles of New Brunswick, 16; John P. Wall, Philip French and New Brunswick, N.J. In His Day (New Brunswick: Thatcher-Anderson Company, 1943), 16-7, 19; and Betty J. Cosans, “Archaeological Investigations of a Proposed Urban Redevelopment Site, New Brunswick, New Jersey” (report, New Jersey Historic Preservation Office, 1983), 17-8, 22-3.

${ }^{4}$ New York Weekly Journal, February 16, 1741, and Boston Evening Post, March 23, 1741, in Nelson, “Extracts from American Newspapers, Relating to New Jersey, Vol. 2, 1740-1750,” 70, 79.

${ }^{5}$ Benedict, New Brunswick in History, 30; Wall, The Chronicles of New Brunswick, 20, 25.

${ }^{6}$ Jedidiah Morse, The American Geography; or, A View of the Present Situation of the United States of America (Elizabethtown: Shepard Kollock, 1789), 289. This was the first detailed account of the New Brunswick Copper Mining and Processing Complex to appear in print, and it was repeated or paraphrased in nearly all of the sources 


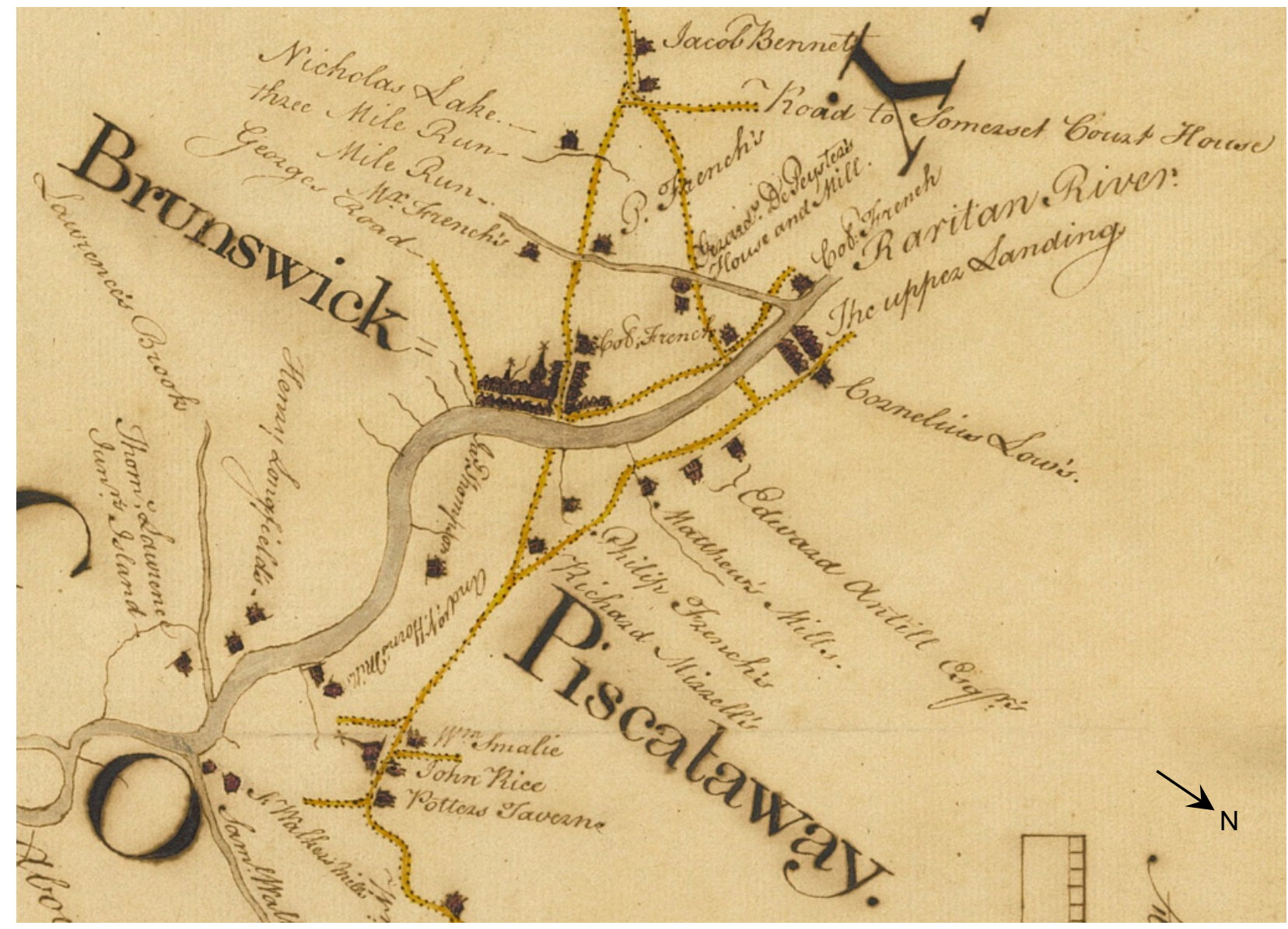

Figure 2. Map showing New Brunswick and its vicinity, and the various holdings of Philip French, in 1745. Source: “A Map of the Road from Trenton to Amboy copied (from a survey made by John Dalley for James Alexander Esquire) by G. Bancker,” 1762.

(Copy of Manuscript Map, Princeton University Library Manuscript Division, Department of Rare Books and Special Collections).

Elias Boudinot (1706-1770) was of Huguenot descent and the son of Elie (or Elias) Boudinot, a

New York City merchant. In 1728 the younger Boudinot completed his apprenticeship as a silversmith and removed to Antigua, where other members of the Boudinot family were already well-established. He returned to America circa 1736, eventually settling in Philadelphia, where he was active as a silversmith and merchant for nearly two decades. The opportunity represented

that subsequently dealt with the subject. No surviving copy of a French-Boudinot lease has been discovered to date. A number of French leases were recorded within what is now referred to as the "French Lease Book," which is held by the Rutgers University Libraries Special Collections and University Archives, but no leases associated with the copper mine property were recorded in this book. 
by the New Brunswick copper venture prompted Boudinot to leave Philadelphia circa 1752 and establish himself at Rocky Hill, a short distance to the west of New Brunswick, before moving to Princeton several years later. ${ }^{7}$

Morse's account of the "copper mine at New Brunswick" continued, stating that Boudinot:

took in several partners, and about the year 1751 opened a pit in the low grounds, about 2 or 300 yards from the river. He was led to this spot by a friend of his, who, a little before, passing by at three o'clock in the morning, observed a body of flame arise out of the ground, as large as a common sized man, and soon after die away. He drove a stake on the spot. ${ }^{8}$

Although the significance of the "body of flame" is unclear, the potential of the New Brunswick copper deposits led Boudinot and his partners to organize themselves as the Brunswick Copper Mine Company and put up the capital necessary to commence operations. ${ }^{9}$ Morse summarized the activities of Boudinot's venture as follows:

About fifteen feet deep, Mr. Boudinot came on a vein of bluish stone, about two feet thick, between two perpendicular loose bodies of red rock, covered with a sheet of pure virgin copper, a little thicker than gold leaf. This bluish stone was filled with sparks of virgin copper, very much like copper filings, and now and then a large lump of virgin copper from five to thirty pounds weight. He followed this vein almost thirty feet, when, the water coming very fast, the expence became too great for the company's capital. A stamping mill was erected, when by reducing the bluish stone to a powder, and washing it in large tubs, the stone was carried off and the fine copper was preserved, by which means many tons of the purest copper was sent to England without ever passing through the fire; but labour was too high to render it possible for the company to proceed. Sheets

\footnotetext{
${ }^{7}$ William Nelson, "New Jersey Biographical and Genealogical Notes From the Volumes of the New Jersey Archives," Collections of the New Jersey Historical Society 9 (1916), 49; George A. Boyd, Elias Boudinot: Patriot and Statesman, 1740-1821 (New York: Greenwood Press, 1952), 3-7; Harry B. and Grace M. Weiss, The Old Copper Mines of New Jersey (Trenton: The Past Times Press, 1963), 50; J.J. Boudinot, The Life, Public Services, Addresses, and Letters of Elias Boudinot (New York: Da Capo Press, 1971), 2:390-2; and Barbara L. Clark, E.B.: The Story of Elias Boudinot IV, His Family, His Friends, and His Country (Philadelphia: Dorrance \& Company, 1977), 1-7. It is worthy of note that Elie Boudinot was the owner of an interest in a copper mine in Connecticut during the early part of the 18th century.

${ }^{8}$ Morse, The American Geography; or, A View of the Present Situation of the United States of America, 289.

${ }^{9}$ Brunswick Copper Mine Co. Minutes of Meetings, 11 and 12 August, 1762 (Seymour Adelman Letters and Documents Collection, Bryn Mawr College Library Special Collections Department).
} 
of copper about the thickness of two pennies, and three feet square, on an average, have been taken from between the rocks, within four feet of the surface, in several parts of the hill. At about fifty or sixty feet deep, they came to a body of fine solid ore, in the midst of this bluish vein, but between rocks of a white flinty spar, which, however, was worked out in a few days. ${ }^{10}$

It is claimed that the origins of New Jersey's copper mining industry can be traced to the 17th century and the working of the Pahaquarry Mine in what is now Hardwick Township in Warren County. The first fully documented activities occurred circa 1715 at the famous Schuyler Mine in North Arlington Borough in Bergen County, where a substantial copper deposit was worked until well into the 20th century. A number of other mines were also opened elsewhere in New Jersey during the first quarter of the 18th century. A strong interest in the potential of local copper deposits continued to be seen during the remainder of the colonial period, notably among the region's social and political elites. It was this entrepreneurial atmosphere that led to the development of the New Brunswick Copper Mining and Processing Complex by Philip French, Elias Boudinot, and additional well-to-do investors from New Jersey, New York City, and Philadelphia at mid-century. Despite this enthusiasm, the colonial copper industry enjoyed, for the most part, only very limited success, and most ventures were abandoned prior to the outbreak of the American Revolution. ${ }^{11}$

The operations within the New Brunswick Copper Mining and Processing Complex would ultimately come to include both extractive (mining) and water-powered industrial (processing) operations. The latter activity is of particular significance as copper processing was

\footnotetext{
${ }^{10}$ Morse, The American Geography; or, A View of the Present Situation of the United States of America, 289-90. ${ }^{11}$ See Herbert P. Woodward, "Copper Mines and Mining in New Jersey,” New Jersey Geological Survey Bulletin 57 (1944); Weiss and Weiss, The Old Copper Mines of New Jersey; Collamer M. Abbott, "Colonial Copper Mines,” The William and Mary Quarterly, 3d ser., vol. 27, no 2 (April 1970): 295-309; James A. Mulholland, History of Metals in Colonial America (Tuscaloosa: University of Alabama Press, 1981); and Brendan McConville, These Daring Disturbers of the Public Peace: The Struggle for Property and Power in Early New Jersey (Philadelphia: University of Pennsylvania Press, 2003).
} 
extremely rare in the American colonies, with the vast majority of colonial copper ore shipped to England for processing. This lack of colonial processing facilities is likely a consequence of the absence of the other metals necessary for the production of brass and bronze, a relatively limited local demand for other copper products, and various efforts promoting processing and mercantile interests in England. ${ }^{12}$

On October $22^{\text {nd }}, 1757$ a lease agreement was concluded between "Philip French of New Brunswick....Gentleman....and Benjamin Koster of Philadelphia....Carpenter” involving a property located in New Brunswick. The said property was bounded on the northeast by the Raritan River and "the road that Leads from New Brunswick aforesaid along rariton River," on the west by "Mile Run," and on the south by a line north of and parallel to "the road that Leads from the ferry to Trenton.” Koster was granted the full rights to "the Mines Minerals, Oar and Fossils" located on the property, including both the already identified deposit known as the "Black Vein" and any additional copper deposits that he might discover. To accomplish these ends he had the right “of Diggin Delving Sinking Constructing and making any Holes Cavaties Driftways Levels Trenches, \& Storehouses or any Other works or pieces of Art” that he felt were necessary. To provide for the "washing Cleansing Manufacturing and preparing for Sale” of the products of his pursuits he was granted control of "the Waters Water Courses Springs \& Rivulets" on the property, along with the right to excavate any necessary "Wells, Ditches and Courses \& thereon Erect any works” to meet his water supply needs. The term of the lease was to be 35 years, with the consideration due to French set at a full third of all profits gleaned from Koster's efforts. It is important to note that one of the witnesses to this document was Elias

\footnotetext{
${ }^{12}$ See Woodward, “Copper Mines and Mining in New Jersey;” Weiss and Weiss, The Old Copper Mines of New Jersey; Abbott, "Colonial Copper Mines;” Mulholland, History of Metals in Colonial America; and William E. Burns, Science and Technology in Colonial America (Greenwood Publishing Group, Westport, Connecticut, 2005).
} 
Boudinot. $^{13}$

In 1759 a notice appeared in a Philadelphia newspaper offering for sale a one-seventh share “of a Copper-Mine, at Brunswick, call’d French's Mine,” along with shares in two other copper mines located along the base of the south side of the First Watchung Mountain in Bridgewater Township in Somerset County. These shares were held by John Reynolds, John Kidd, and David McMurtrie, who, like Koster, were all residents of Philadelphia. ${ }^{14}$ The same shares were again advertised for sale later that year, and it was noted that any sale would include “all the ore that is above ground, pumps, mills and other utensils respectively belonging to each mine."15

A second lease agreement was concluded between Philip French and Benjamin Koster, who was again described as a "Carpenter," on March 25 ${ }^{\text {th }}$, 1761. After citing the earlier lease, it was stated that Koster had determined it to be necessary "to have....Mile Run....Turn'd and brought Down to the Mine, pitts or Works now in Working \& the Erecting making and raising a Stamping Mill Furnace and Water Engine for the Use and benefit of the said Mine and Works.” Koster had sought, and through this document was receiving, a 25-year extension of the original lease, with full rights to the "Copper Oar and Oar of any other Metall” within "all Pitts and Veins of Oar now Open and known or that Shall or may hereafter be found out or Discovered by Digging Trenchin Searching or Otherways however lying or being” on the property described in the earlier agreement. The new lease went on to describe in some detail the several new rights that French was granting to Koster. The latter was to have the ability to construct "any Dam or

\footnotetext{
${ }^{13}$ West Jersey Deeds (New Jersey State Archives), Book O, 317.

${ }^{14}$ Pennsylvania Journal, 27 September, 1759 in William Nelson, ed., "Extracts from American Newspapers, Relating to New Jersey, Vol. 4, 1756-1761,” Documents Relating to the Colonial History of the State of New Jersey 20 (1898), 382.

${ }^{15}$ Pennsylvania Journal, 20 December, 1759 in Nelson, “Extracts from American Newspapers, Relating to New Jersey, Vol. 4, 1756-1761,” 400.
} 
Dams or Other works” necessary on Mile Run and to "Cut Dig and make....a Canal Gut Drain or Water Course." Koster was also to be able "to Erect raise and build....any Engine work or Machine for the pumping Draining raising up or Carrying Off the Waters out of the said Mine Pitts or Works," and to build "near the said Works and to the Eastward of the Engine house....a Stamping Mill and Furnace and all Other Necessary buildings for the Use of the Said Mine and Works.”16

In return for these various rights Koster again agreed to pay French a full one-third of the profits earned during the term of the second lease. Koster was also required to commence work on the new water supply system within three months and to complete the said work within three years. If this was not accomplished, or if the new system was completed but remained unused for a period of ten years, full water rights would revert to French. Additionally, it was noted that the water supply system would need to pass through lands owned by others - should any successful legal actions be brought, it would be the responsibility of Koster and "the Mine Company" to make any compensatory payments. The lessee was also required to guarantee that he would employ at least three miners and three laborers for three months out of the year, with a failure to comply to result in the termination of the lease. Koster also promised to fill any "Pitts Shafts Wells or Holes" and "Shafts for Air” that are abandoned and to insure that the workings do not undermine "any building now Erected” on the leased property. ${ }^{17}$

Detailed descriptive information and a graphic representation of the furnace that was built on the property leased from Philip French were attached to a undated letter written by Elias Boudinot to a "Mr. White." Boudinot sent "the draft of the furnace” to White, noting that he

\footnotetext{
${ }^{16}$ West Jersey Deeds, Book S, 1.

${ }^{17}$ Ibid. On April $7^{\text {th }}, 1761$ Ann French, the wife of Philip French, recognized the rights granted to Benjamin Koster in the leases of 1757 and 1761, along with his right to two-thirds of the profits gained from "a Certain Mine or Mines of Copper” on the property defined in those two leases; see West Jersey Deeds, Book S, 10.
} 
hoped it would supplement "the demensions you have taken," and offered the opinion that "it wou'd be much to the advantage of the gentlemen concern'd at rocky hill, if they roasted their oar, in a roasting oven built for the purpose, before they stamp'd it.” The drawing of the furnace represented in detail the various components of the structure, with notes keyed numerically to the graphic (Figure 3A). A separate page provided the "Dimensions of the Furnace at Brunswick for Smelting of Copper Oar” and also noted that the building within which the furnace was located (“the House”) measured “32 by 20 Feet” (Figure 3B). ${ }^{18}$

The focal point of the New Brunswick Copper Mining and Processing Complex was formerly located within what is now referred to as the Voorhees Mall of Rutgers University, which is bounded on the east by George Street, north by Seminary Place, west by College Avenue, and south by Hamilton Street. It seems most likely that the original mine shaft was excavated here, and that the complex's entire processing facility, which eventually would consist of the furnace detailed above, a stamping mill, and an engine house, was also sited here on a small watercourse that came to be known as Mine Run. Ore processing would have involved the roasting of the excavated ore in the furnace, followed by the crushing of the roasted ore in the stamping mill. Mining activities eventually extended well beyond the limits of the Voorhees

\footnotetext{
${ }^{18}$ Letter from Elias Boudinot to Mr. White (with Attachments), March 27th, n.d., Robert Morris Papers (Rutgers University Libraries Special Collections and University Archives). Boudinot, while including the day and month on his letter, did not include the year - at some point Rutgers archivists proposed the year 1756, but the French-Koster leases make it clear that this is a bit too early. Boudinot's correspondent is presumed to be Anthony White (17171787), the wealthy builder and occupant of the dwelling known as the "White House," and later "Buccleuch," which still stands within New Brunswick’s Buccleuch Park. The mine at "rocky hill” was also known as the Griggstown Mine and was located southwest of New Brunswick near the villages of Rocky Hill and Griggstown - the contemplated furnace does not appear to have ever been constructed here. See William Nelson, Note on Anthony White, "Extracts from American Newspapers Relating to New Jersey, Vol. 3, 1779," Documents Relating to the Colonial History of the State of New Jersey, Second Series 3 (1906); William H. Benedict, "Historic 'Buccleuch:' Its Successive Owners,” Proceedings of the New Jersey Historical Society, New Series 4 (1921); Elmer T. Hutchinson, ed., "Calendar of New Jersey Wills, Administrations, Etc., Vol. 6, 1781-1785,” Documents Relating to the Colonial, Revolutionary and Post-Revolutionary History of the State of New Jersey, First Series 35 (1939); Woodward, "Copper Mines and Mining in New Jersey;” Weiss and Weiss, The Old Copper Mines of New Jersey; and Abbott, "Colonial Copper Mines."
} 


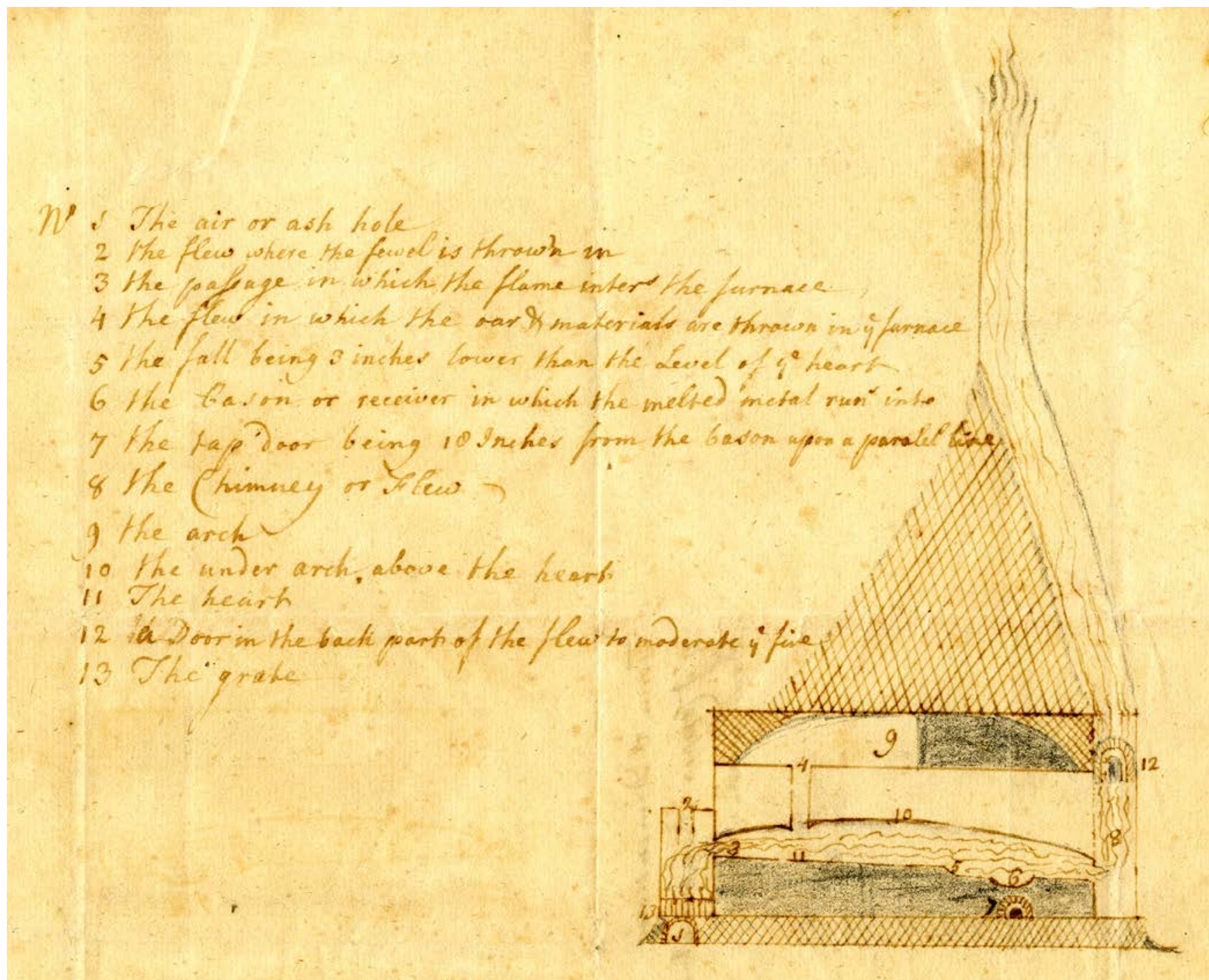

Figure 3A. Contemporary drawing of the furnace at the New Brunswick Copper Mining and Processing Complex. Source: "Dimensions of the Furnace at Brunswick for Smelting of Copper Oar [sic]," enclosure 1 of 2 with letter of March 27, [1756?] from E. Boudinot to [Anthony] White.

(Robert Morris Papers, Box 2, Rocky Hill Copper Mine Correspondence, Special Collections and University Archives, Rutgers University Libraries).

Mall, most notably into the area to the east currently occupied by the northern portion of the Johnson \& Johnson Corporate Headquarters, as the complex came to include additional shafts and associated horizontal workings. Finally, the property's water supply needs, which were inadequately met by Mine Run, were supplemented through the construction of a dam on Mile Run and the excavation of a half-mile long tunnel to carry water from the pond formed by the 
Dimentions of the Aurnaus at Bunvisits bos Imelting of gropers tase.

The Honte 82 by 20 Mecto.

outidide lenghto of the furnace $101 / 2$ of 6 Heit.

Frem the Surface of the grownd to the firs holes, which

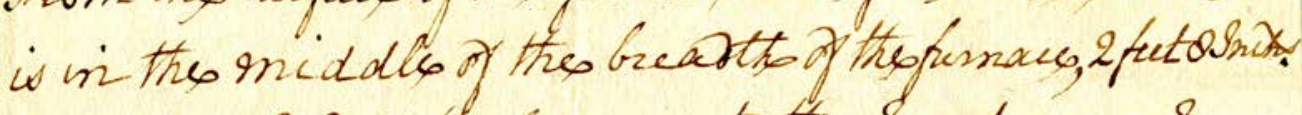
Frome thes ind of the furnaces to thes exp dorsone sap holes 6 sect o inched.

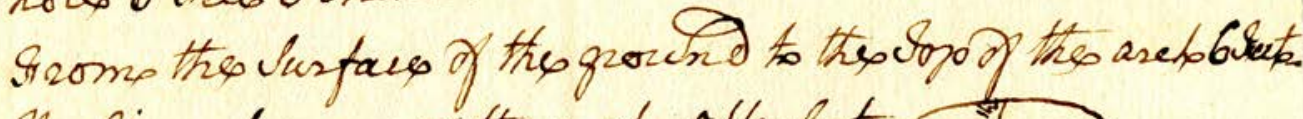

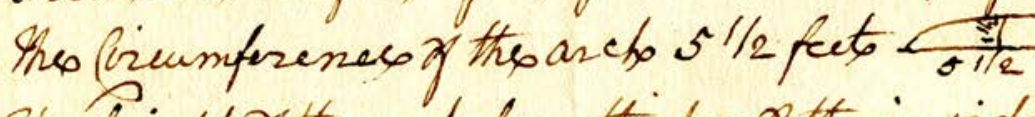

The hiighto of the asche froms this topo of the invideofy thes Surnace / $1 / 2$ fut.

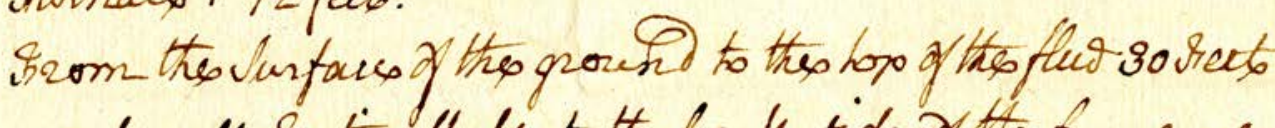

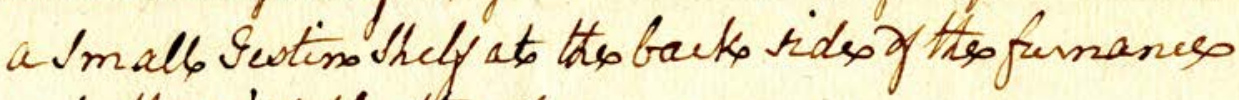
in the middles theroy.

The thickefs of the fountation is Mnehes.

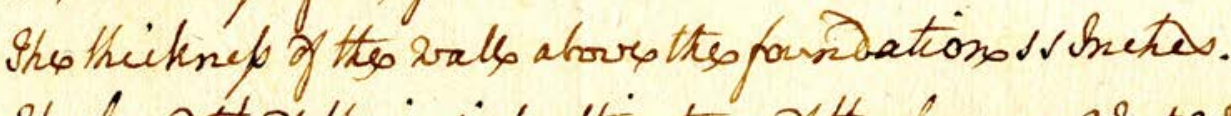

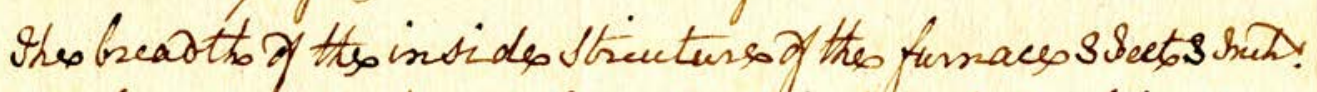

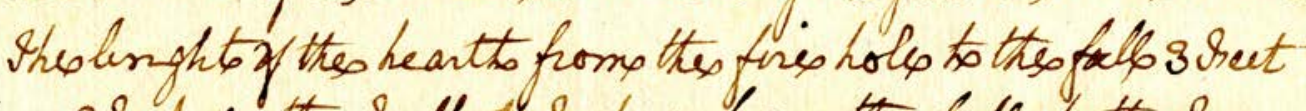
3 inewes, thes salle th inches, frome the falle to thes sap

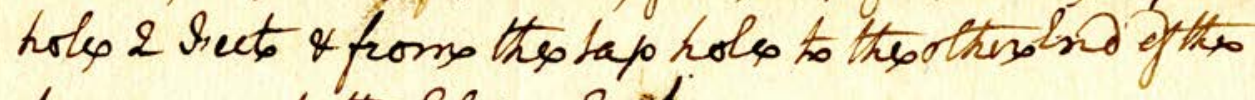
fumaus on to thes slew 1 of do

Figure 3B. Specifications for the furnace at the New Brunswick Copper Mining and Processing Complex.

Source: "Form \& Dimensions of [the ] Furnace at Brunswick," enclosure 2 of 2 with letter of March 27, [1756?] from E. Boudinot to [Anthony] White.

(Robert Morris Papers, Box 2, Rocky Hill Copper Mine Correspondence, Special Collections and University Archives, Rutgers University Libraries). 
dam to the processing facilities to the east. ${ }^{19}$

The first fairly detailed historical discussion of the features of the New Brunswick Copper Mining and Processing Complex appeared in New Brunswick’s first city directory, which was published in 1855. The tunnel (or "gallery") extending from Mile Run to the site of the former processing facility was noted, as was the large dam on Mile Run sited a short distance to the north of the Hamilton Street crossing that had created a battery pond and raised the water to the level necessary to reach the tunnel opening. It was noted that the tunnel was large enough to admit "a man with a wheel-barrow," with the dimensions later given as 8 feet in height and 5 feet in width (see below). A series of shafts were excavated along the length of the tunnel to allow for the removal of material during excavation and to provide ventilation. These shafts, which were not directly associated with any actual mining activities, were apparently often erroneously referred to as "mine holes."20

The tunnel's eastern outlet was described as being located in "the gully in the rear of the house recently erected by Theo. G. Neilson, Esq.” (this house still stands at 502 George Street and is utilized by the Rutgers University School of Social Work). The gully in question was cut by Mine Run, which formerly ran eastward across the northern section of the Voorhees Mall and

\footnotetext{
${ }^{19}$ It is worthy of note that an interesting small scale copper processing facility has been identified archaeologically at the former village and river port of Raritan Landing, located just upriver from New Brunswick. A stone hearth feature within the remains of a small building has been interpreted, largely through the chemical analysis of associated soils, as having been a focus of coppersmithing activities. Of particular interest is the fact that Cornelius Van Horne and Joseph Reade, the owners of the property on which the coppersmith shop was sited, were married to Elizabeth and Anne French, respectively, the sisters of Philip French. See Grace H. Ziesing et al., "Route 18 Section 2A Extension Project Technical Report No. 5 - The Reade/Bray Property [28-MI-179] and the Low/Pool Meadow Property [28-MI-203]" (report, New Jersey Historic Preservation Office, 2011) and Rebecca Yamin, "Rediscovering Raritan Landing” (report, New Jersey Department of Transportation, 2011).

${ }^{20}$ A Directory of the City of New-Brunswick, for 1855 (New Brunswick: J. Terhune, 1855), 20-1. For later discussions of the tunnel see "The Mines of New Brunswick," Daily Press, December 12, 1901); Ralph Voorhees, "Franklin Township Historical Notes," Somerset County Historical Quarterly 4, no. 1 (1915); Wall, The Chronicles of New Brunswick; Philip P. Hindes, "New Brunswick's Famed Copper Mine Definitely Located by Charles Deshler" (uncited newspaper article, Rutgers University Libraries Special Collections and University Archives, February 21, 1937); and Woodward, "Copper Mines and Mining in New Jersey.”
} 
drained into the Raritan River about 750 feet above the present Northeast Corridor bridge. It was noted that the tunnel still conveyed water in 1855, with its point of exit commonly referred to as the "Boiling Spring." It was also noted that there had formerly been a dam on Mine Run a short distance downstream from the tunnel's outlet and to the west of the present George Street. This dam retained a small pond that provided the water required to power the stamping mill, used in crushing the excavated ores, and the engine running the pumping machinery necessary for the removal of ground water from the nearby mine shaft and its associated underground workings. The stamping mill and the engine house would have been sited just downstream (east) of the Mine Run dam, with, as noted above, the tunnel from Mile Run serving to augment the water available within the smaller watercourse. The presence of several additional shafts was also noted, including one within the present Johnson \& Johnson property from which a "long pump rod,” a remnant of a separate pumping apparatus, had recently been removed. It was further noted that the former mine workings also included horizontal drifts (excavations created through the reduction of an ore deposit) and adits (excavations made to provide access to ore deposits) associated with the various shafts. ${ }^{21}$

In 1875 Cornelius C. Vermeule produced a plan and profile of the former tunnel from Mile Run while a student at Rutgers College (Figure 4). Vermeule, who later would serve as a

\footnotetext{
${ }^{21}$ Ibid, 21. Clayton (in History of Union and Middlesex Counties, 645) also discussed the siting of the stamping mill in the hollow below the New Brunswick Theological Seminary (sited on the north side of the present Seminary Place) in 1882. George H. Cook (in “The New Brunswick Copper Mines,” New Brunswick Daily Home News, 21 May, 1886) supported this statement, adding that "Its exact location cannot be identified, as the valley [of Mine Run] has been filled up very much since streets have been graded across it." Cook was, of course, an excellent source as he was both New Jersey's preeminent geologist and also the occupant of the Cook/Demarest House (542 George Street; also known as Riverstede), sited just to the north of the former Mine Run at the southwest corner of George Street and Seminary Place. This dwelling, which is listed on the New Jersey and National Registers of Historic Places and now houses the Rutgers University School of Social Work, was designed by Cook in conjunction with architect/builder Charles Graham and completed in 1868 - see Geo. H. Cook to C. Graham Esq., 19 April, 1866, George H. Cook Papers, Rutgers University Libraries Special Collections and University Archives; The American Architect and Building News 41, no. 951 (8 July, 1893), 17; Michael C. Barr, "Demarest House” (National Register of Historic Places Nomination form, New Jersey Historic Preservation Office, 1976); and Jean W. Sidar, George Hammell Cook: A Life in Agriculture and Geology (New Brunswick: Rutgers University Press, 1976).
} 


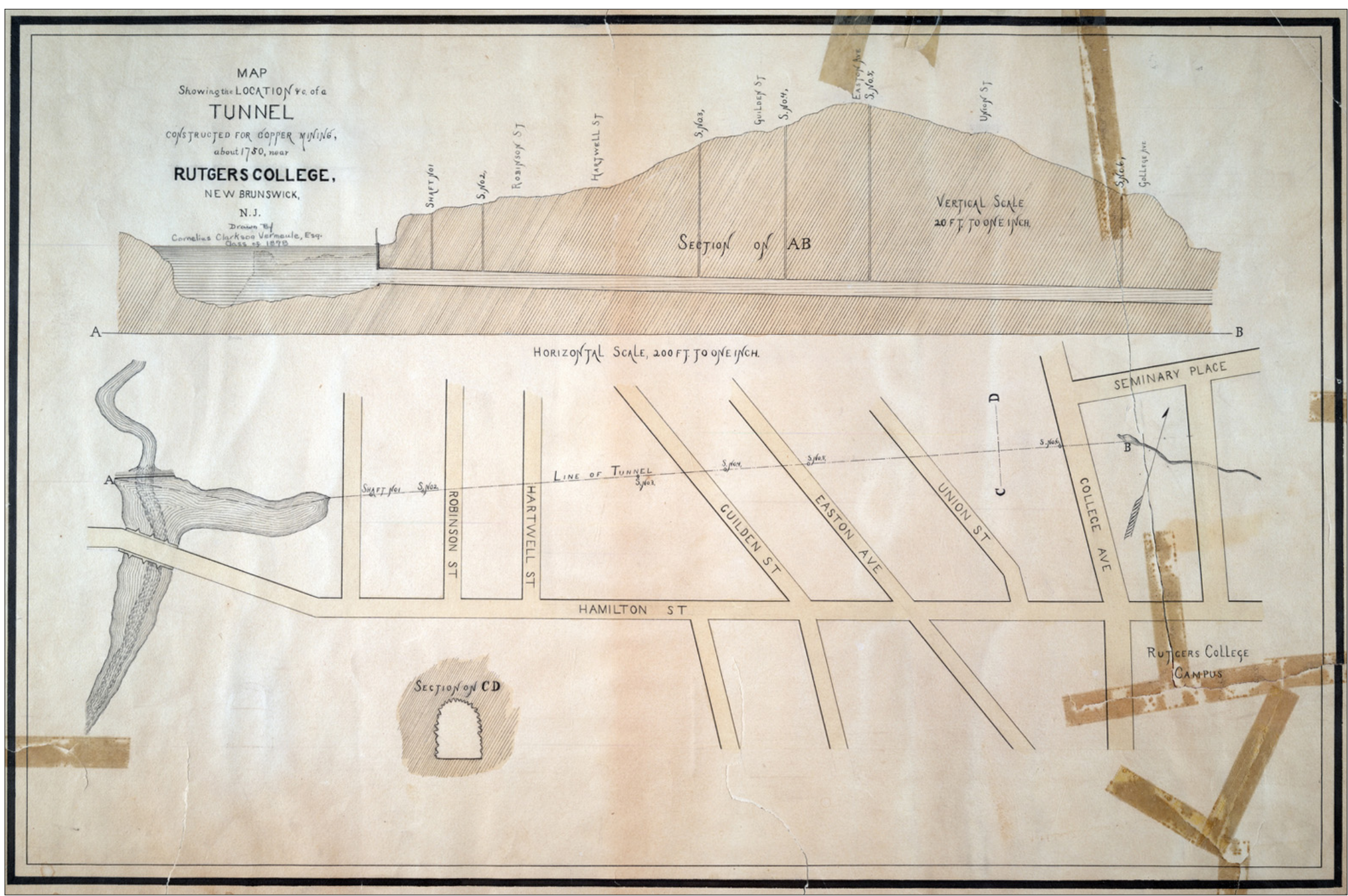

Figure 4. Plan and profile of the New Brunswick Copper Mining and Processing Complex tunnel from Mile Run.

Source: Cornelius C. Vermeule, "Map Showing the Location etc. of a Tunnel Constructed for Copper Mining, about 1750, near Rutgers College, New Brunswick, N.J.," 1875.

(Manuscript Map, Special Collections and University Archives, Rutgers University Libraries [http://dx.doi.org/doi:10.7282/T3DZ08TJ]). 
topographer and cartographer with the New Jersey Geological Survey, depicted the tunnel's intake on the east side of the run to be about 300 feet to the north of Hamilton Street. The intake was located at the head of Strong's Pond, an impoundment formed either by the still extant dam built at the time of the tunnel's construction or by a more recent replacement. The tunnel, shown to measure, as reported earlier, 8 feet by 5 feet, then ran eastward roughly parallel to Hamilton Street, its course marked on the surface by a total of 6 ventilation shafts. The tunnel's outlet at the spring (designated " $\mathrm{B}$ " on the plan) was described as being sited immediately to the rear of Professor Theodore S. Doolittle's house at 18 Seminary Place (now owned by Rutgers and known as the Linguistics Office Building). It was noted that this impressive underground channel, which was more than a half mile in length and up to 30 feet below ground, still carried water from the pond to the spring and Mine Run. Vermeule, relying on Morse's account, placed the date of the tunnel's construction as occurring shortly after the excavation of the first shaft in $1751 .^{22}$

The shaft on the Johnson and Johnson property noted above was described as being sited “at the north-east corner of the Cotton Factory” located on the north side of Hamilton Street (and east of today's George Street - this segment of Hamilton is now known as Johnson Drive) in 1855. This shaft was further described as providing access to the mine's horizontal workings, which would have presumably consisted of both drifts and adits. It was claimed that these horizontal workings included elements that extended beneath the bed of the adjacent Raritan River, a considerable distance representing, if accurate, some very impressive below ground

\footnotetext{
${ }^{22}$ See also the Cornelius C. Vermeule Papers (Rutgers University Libraries Special Collections and University Archives) and Dumoulin (Cornelius C. Vermeule), "The Copper Mine Tunnel,” The Targum, April, 1877 for additional information on Vermeule's work on the tunnel as a student. See also Cook, "The New Brunswick Copper Mines;” Voorhees, "Franklin Township Historical Notes," 27; Wall, The Chronicles of New Brunswick, 328; and Woodward, "Copper Mines and Mining in New Jersey," 101 for additional information on the tunnel. It is now clear that a 1751 date of construction for the tunnel is several years too early.
} 
exertions. $^{23}$ In 1834 it was stated that some of the mine’s “excavations have been extensive," with at least one deep shaft and an adit which was said to have been "driven several hundred yards beneath the bed of the river." ${ }^{24}$ George H. Cook, then serving both as the New Jersey State Geologist and a Rutgers College professor, placed the shaft on the north side of Hamilton "where the front building of the Norfolk and New Brunswick Hosiery Company [the former cotton factory noted above] now stands." He went on to say that "the S.E. [southeast] wall of that building was set several feet out upon the street to avoid the old mining diggings.”25

It seems probable that neither of the two shafts mentioned above - sited at the northeast and southeast corners of the cotton factory, respectively - was the original shaft that was excavated with the commencement of work circa 1751. Vermeule placed this first shaft in the Mine Run hollow to the rear of the Doolittle House (18 Seminary Place) and in close proximity to the site of the property's processing facilities. ${ }^{26}$ Although conclusive evidence remains unidentified, this view seems perhaps most logical as it would have been desirable to have the mine's initial shaft located close to the processing center. Other shafts elsewhere on the property, such as the two mentioned above, would, following this line of reasoning, represent expansions of the mine, and at least some of these may have been connected to one another by adits and/or drifts.

${ }^{23}$ A Directory of the City of New-Brunswick, for 1855, 20. See also "The Mines of New Brunswick" and Voorhees, "Franklin Township Historical Notes," 27.

${ }^{24}$ Thomas F. Gordon, Gazetteer of the State of New Jersey, (Trenton: Daniel Fenton, 1834), 11. These excavations beneath the river make the significant ground water problems encountered by the mine's various operators quite understandable.

${ }^{25}$ Cook, "The New Brunswick Copper Mines." His views were repeated in Wall, The Chronicles of New Brunswick, 328 and Hindes, "New Brunswick's Famed Copper Mine Definitely Located by Charles Deshler.” Cook (in his Geology of New Jersey [Trenton: New Jersey Geological Survey, 1868], 224, 678) also claimed that there was another opening (presumably an adit) providing access to the mine on the bank of the river about 600 feet to the north of the railroad bridge; Woodward (in "Copper Mines and Mining in New Jersey," 102) also proposed that there might have been some workings along the bank of the river.

${ }^{26}$ Cornelius C. Vermeule Papers; Dumoulin (Vermeule), “The Copper Mine Tunnel.” 
In 1761 Elias Boudinot advertised his one-fourteenth share in "the Copper-Mine and Works of New-Brunswick, commonly called French’s Mine” as available for purchase. He also offered his dwelling in Princeton for sale and asked that interested parties apply either to him in Princeton or to his son Elias Boudinot, a lawyer in Elizabethtown. ${ }^{27}$ The elder Boudinot left Princeton shortly after placing this advertisement and settled in Elizabethtown, where many members of his family, including his sons Elias and Elisha Boudinot, already resided. It is unclear whether or not Boudinot retained his interest in the copper mining complex during his tenure at Elizabethtown. ${ }^{28}$ He did not, however, attend the meetings of the Brunswick Copper Mine Company that were held in August of 1762, suggesting perhaps that he had either sold off his share or that he had reduced his involvement in the Company’s operations. ${ }^{29}$

Yet another notice offering a one-fourteenth share of "the New Brunswick Copper Mine” was published by William Bradford of Philadelphia in 1765. It was stated that the mine "now yields excellent solid oar, and is so circumstanced, that the purchaser will be at no charges in carrying it on, and that it may be worked to the very best advantage, the gentlemen already concerned, have agreed with a person to build a smelting house.”30 This latter reference appears to suggest that the complex's smelting furnace was not built until circa 1765, or that the smelting

\footnotetext{
${ }^{27}$ Pennsylvania Gazette, 5 November, 1761 in Nelson, "Extracts from American Newspapers, Relating to New Jersey, Vol. 4, 1756-1761,” 626-7.

${ }^{28}$ Nelson, New Jersey Biographical and Genealogical Notes From the Volumes of the New Jersey Archives, 49; Boyd, Elias Boudinot: Patriot and Statesman, 1740 - 1821, 16, 18; Clark, E.B.: The Story of Elias Boudinot IV, His Family, His Friends, and His Country, 21, 28. The younger Elias Boudinot later served in the United States Congress, both during and after the American Revolution, and also as the Superintendent of the United States Mint. ${ }^{29}$ Brunswick Copper Mine Co. Minutes of Meetings, 11 and 12 August, 1762. The meetings were attended by Charles Batho, Daniel Benezet, Isaac Coates, John Coates, Henry Drinker, the lease holder Benjamin Koster, Isaac Levy, Anthony Morris, Joseph Morris, Samuel Morris, and Thomas Say. Anthony Morris died in the following year, and the codicil to his will (drawn up only two days before his death) noted the share he held in the copper mine in New Brunswick that was purchased from Thomas Preston and empowered his executors to continue to provide funds for the operation of the mine; see R. Winder Johnson, comp., The Ancestry of Rosalie Morris Johnson (Philadelphia, 1905), 156.

${ }^{30}$ Pennsylvania Journal, January 31, 1765 in William Nelson, ed., “Extracts from American Newspapers, Relating to New Jersey, Vol. 5, 1762-1765,” Documents Relating to the Colonial History of the State of New Jersey 24 (1902), 477-8.
} 
facility referenced here was to be built as a replacement for the earlier furnace. Another notice of interest appeared later that same year as assistance was sought in the recovery of a runaway African-American slave named Jack. It was stated that "it is supposed that he will endeavour to travel to New Brunswick, as he has lived formerly at the Copper Mines there.”31

In 1765 Benjamin Koster appears to have remained active in the workings of the New Brunswick Copper Mining and Processing Complex as in August of that year he was recorded as a resident of New Brunswick. ${ }^{32}$ He was still living there early in 1766 when he conveyed various properties that he had accumulated in the vicinity of the works to Thomas Say, one of his partners in the Brunswick Copper Mine Company. ${ }^{33}$ The reason for these conveyances can be inferred as later that same year Koster died, with his will being probated in September of 1766. His will, which was drawn up in April of that year, and within which he described himself as a house carpenter, included a reference to Anthony Benezet, who he described as his friend and named Thomas Say to serve as his executor. ${ }^{34}$

Azariah Dunham's map showing the boundary line between Middlesex and Somerset Counties in 1766 provides the best known contemporary graphic representation of features associated with the New Brunswick Copper Mining and Processing Complex (Figure 5). Both the "stamping Mill" and a "Mine House" were shown on Mine Run to the west of the crossing of the River Road and north of Philip French's dwelling house. The exact nature of the mine house is somewhat unclear, but it seems possible that it was either the building housing the furnace, the engine house, or the head house for the shaft sited at this location. Also unclear is the absence of

\footnotetext{
${ }^{31}$ Pennsylvania Gazette, 4 July, 1765 (www.accessible.com/accessible/about/aboutPG.jsp).

${ }^{32}$ West Jersey Deeds, Book AB, 28.

${ }^{33}$ West Jersey Deeds, Book H3, 307, 312, and 316.

${ }^{34}$ Will of Benjamin Koster, Philadelphia County, Pennsylvania Wills, 1682-1819 (Philadelphia: Historical Society of Pennsylvania, 1900). Benezet and Say were, of course, also Koster's partners in the Brunswick Copper Mine Company.
} 


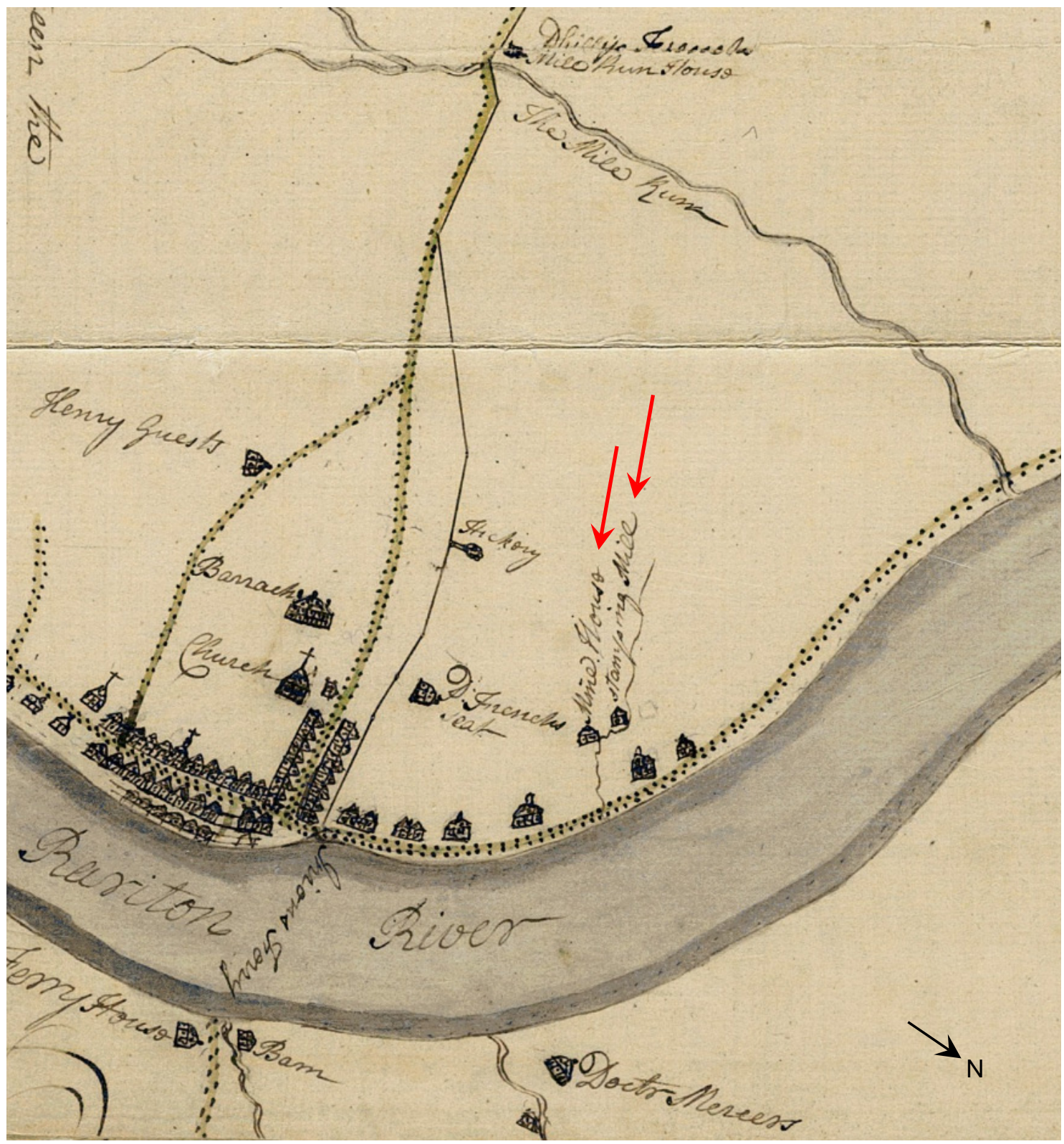

Figure 5. Map showing the "Mine House” and "stamping Mill” (arrows) of the New Brunswick Copper Mining and Processing Complex.

Source: Azariah Dunham, “A Map of the Division line Between the Counties of Middlesex and Somerset," 1766.

(Copy of Manuscript Map, Princeton University Library Manuscript Division, Department of Rare Books and Special Collections).

whichever building or buildings is not depicted, and this may indicate that activities on the property were either diminished or had ceased altogether by this time. An unidentified structure was depicted in the same location on Mine Run on a map of Somerset County surveyed in 1766 
and reproduced for the use of the British Army during the American Revolution. ${ }^{35}$

In 1767 the announcement of the public sale of the landholdings belonging to the estate of Benjamin Koster of Philadelphia was published in a newspaper of that city. Included among the deceased's properties was a one-twenty-eighth share "of the lease and leases of the copper mine, stamping mill or mills, situate in New Brunswick.....with all the utensils, thereunto belonging," along with a small interest in one of the copper mines at the base of the First Watchung Mountain. Those interested in the New Brunswick property were asked to contact Thomas Say, the executor of the estate. ${ }^{36}$ From this it is apparent that Koster had conveyed shares in the French leases to his partners in the Brunswick Copper Mine Company as he retained only a very small share of same. The final reference to the New Brunswick Copper Mining and Processing Complex as a functioning entity is found in Richard Smith’s account of a trip across New Jersey in the spring of 1769, which included a visit to the "Mineral Works" at New Brunswick. ${ }^{37}$

With the approach of the American Revolution and the associated difficult economic climate, New Jersey’s copper mining and processing activities were significantly reduced during the latter years of the colonial period. It was at this point that the operations of the Brunswick Copper Mine Company were abandoned as the economic constraints of the time combined with the mine's severe ground water problems and the relatively low grade of the mine's ores to force

\footnotetext{
${ }^{35}$ Benjamin Morgan, "Plan of Somerset County," copied from the original by John Hills (copy of manuscript map, Rutgers University Libraries Special Collections and University Archives, 1766).

${ }^{36}$ Pennsylvania Journal, 16 April, 1767 in William Nelson, ed., "Extracts from American Newspapers, Relating to New Jersey, Vol. 6, 1766-1767," Documents Relating to the Colonial History of the State of New Jersey 25 (1903), 348-9.

${ }^{37}$ Francis W. Halsey, ed., A Tour of Four Great Rivers (The Hudson, Mohawk, Susquehanna and Delaware) in 1769, Being the Journal of Richard Smith of Burlington, New Jersey (Port Washington, N.Y.: Ira J. Friedman, Inc., 1964), 3.
} 
a shutdown. $^{38}$ Johann D. Schoepf, a surgeon serving with the Hessian forces attached to the British Army during the Revolution, visited New Brunswick in 1783 and astutely cited the proximity of the river and the resultant ground water issues as a primary reason for the mine's abandonment. Schoepf also observed that it was said that more than 12,000 pounds had been expended on what had been a largely unsuccessful venture. ${ }^{39}$ A map of New Brunswick produced during the war depicted Water Street (or the River Road) running northward to its crossing of Mine Run, with a small pond shown on the run a short distance to the west of this crossing. This body of water was almost certainly the pond associated with the former processing facilities, but nothing other than the pond was represented on the map. ${ }^{40}$ Schoepf made specific note of the mining and processing complex in his writings and characterized it as completely abandoned in $1783 .^{41}$

It was also during the Revolution that Philip French experienced a number of significant financial setbacks. In 1775 a notice was posted in a New York newspaper announcing that the his property, both real and personal, located in Middlesex County was to be sold at public auction in response to a number of lawsuits filed by his many creditors. ${ }^{42}$ French's property in Somerset County also came to be involved, including here the land on which both his primary residence on the north side of Albany Street and the New Brunswick Copper Mining and

\footnotetext{
${ }^{38}$ See J. Volney Lewis, “The Newark (Triassic) Copper Ores of New Jersey,” Annual Report of the State Geologist For the Year 1906 (1907) and Woodward, “Copper Mines and Mining in New Jersey” for discussions on the downturn in the New Jersey copper industry during this period.

${ }^{39}$ Alfred J. Morrison, trans. and ed., Travels in the Confederation, 1783-1784: From the German of Johann David Schoepf (Philadelphia: William J. Campbell, 1911), 28.

${ }^{40}$ John Hills, "Sketch of Brunswick," (copy of manuscript map, Rutgers University Libraries Special Collections and University Archives, circa 1780).

${ }^{41}$ Morrison, Travels in the Confederation, 1783-1784: From the German of Johann David Schoepf, 28.

${ }^{42}$ New York Gazette, 29 May, 1775 and 24 July, 1775 in A. Van Doren Honeyman, ed., "Extracts from American Newspapers Relating to New Jersey, Vol. 11, 1775," Documents Relating to the Colonial History of the State of New Jersey 31 (1923), 138-9, 173. See also William S. Stryker, ed., "Extracts from American Newspapers, Vol. 1, 17761777," Documents Relating to the Revolutionary History of the State of New Jersey 1 (1901), 45, 48, 134; and Thomas B. Wilson, ed., Notices from New Jersey Newspapers, 1781-1790 (Lambertville: Hunterdon House, 1988), 48 for subsequent notices relative to public sales involving former French properties in Middlesex County. It can be
} 
Processing Complex were sited. The public sales held by the Somerset County Sheriff in 1775 were unsuccessful, however, as no buyer came forward. ${ }^{43}$ To add further to his problems, French was determined to be a Loyalist in 1778, although he was able to weather this particular storm, and at least some of his financial issues, as he continued as a resident of New Brunswick until the time of his death in $1782 .{ }^{44}$

It was not until after the Revolution that the former French landholdings in the Somerset County section of New Brunswick began to be sold off. In 1783 a public sale resulted in an agreement between the county sheriff and James Parker of New Brunswick for the sale of what was referred to as the property "whereon the sd. Philip French lived and called the homestead," which also included the former copper mining and processing complex, for a consideration of 1800 pounds. This agreement was rendered null and void, however, when Parker did not make good on his promise of payment. In yet another public auction, this one in March of 1786, the French homestead property was finally sold to James Cole of New Brunswick, with the purchase price being a much reduced 500 pounds. ${ }^{45}$ In the following year Cole conveyed the said property to James Parker, who was now residing in Perth Amboy. ${ }^{46}$ Parker (1725-1797) was, in fact, a descendant of a wealthy mercantile family from that city and was himself a successful merchant with extensive landholdings. In 1777 he had been imprisoned as a Loyalist, but he had been released and permitted to remove to Hunterdon County in 1778. It was with the end of the war that he relocated to New Brunswick before returning to Perth Amboy. He would remain a

\footnotetext{
assumed that the failure of the copper venture contributed to French's financial difficulties.

${ }^{43}$ Somerset County Deeds (Somerset County Court House), Book G, 390 and 394. That portion of New Brunswick located to the north of Albany Street was part of Somerset County until 1850.

${ }^{44}$ Francis B. Lee, ed., "Extracts from American Newspapers, Vol. 2, 1778," Documents Relating to the

Revolutionary History of the State of New Jersey 2 (1903), 400-2; Benedict, New Brunswick in History, 32, 52, 114, 256; Wall, The Chronicles of New Brunswick, 247; and Wall, Philip French and New Brunswick, N.J. In His Day, 20-1, 26.

${ }^{45}$ Somerset County Deeds, Book G, 390.

${ }^{46}$ Somerset County Deeds, Book G, 392.
} 
resident of the latter city, and it seems clear that his former French holdings were utilized for various tenant and speculative purposes during the next several decades. ${ }^{47}$

Although no longer active, the former copper mining and processing complex continued as a well-recognized element of New Brunswick's cultural landscape during the remainder of the $18^{\text {th }}$ century. In 1784 King (later Neilson) Street was extended to run north of "Frenches" (or Albany) Street to the road that “crosses a small Brook [Mine Run] by John Halfpenny’s House” (Water Street, or the River Road). This latter crossing was alternatively described as being located at "Halfpenny’s House, near the mines."48 In the following year James Parker offered several properties in New Brunswick as available for purchase, including some obviously derived from the former French estate. Noteworthy among these were a number of lots described as being located “between Doctor Cochran's house [the northernmost dwelling on Water Street] and the mine pits."49 In 1786 an alley was opened up to run between King and Water Streets approximately 150 feet to the north of and parallel to Albany Street. In the document recording the survey for this new alley, King (later Neilson) Street was referred to as the new street "leading to the mines." 50

Morse noted in 1789 that the "works" of the New Brunswick Copper Mining and Processing Complex "lie now wholly neglected, although the vein when left was richer than ever it had been."51 Some of New Jersey's abandoned copper mines were reopened after the Revolution, but nearly all were again shut down during the early decades of the 19th century. In

\footnotetext{
${ }^{47}$ See Benedict, New Brunswick in History, 187-9 for biographical data for James Parker.

${ }^{48}$ Somerset County Road Returns (Somerset County Court House), Book A2, 18. See also A.A. Titsworth, "Map of Land Between College Avenue and the Canal, Copied from a Map draw by Prof. E.A. Bowser from Surveys made in the Winter of 1869-'70" (manuscript map, Rutgers University Libraries Special Collections and University Archives, 1900). King Street was formally renamed Neilson Street in 1830; see Wall, "History of the Streets of New Brunswick," 5.

${ }^{49}$ Political Intelligencer, and New-Jersey Advertiser, 1 March, 1785 in Wilson, Notices from New Jersey Newspapers, 1781-1790, 208.

${ }^{50}$ Somerset County Road Returns, Book A2, 39.
} 
1834 it was claimed that a number of unsuccessful attempts had been made "to renew the mining operations” at New Brunswick, but it appears that no actual extraction of copper of any significance resulted. $^{52}$ There was another boom in copper mining activity within the state during the middle decades of the 19th century, but, again, the former New Brunswick mine did not participate in this movement in any substantial way.

The physical remnants of New Brunswick’s former copper-related pursuits did continue, however, to serve as geographical points of reference in the area to the north of Albany Street. A map of the former French landholdings produced in 1790 included some interesting allusions to the former mining activities once focused in the area to the north of "French's Mansion House" (Figure 6). A dwelling depicted on Water Street just to the south of Mine Run (shown here to have two outlets into the river) was identified as the "Negroes house near ye mines," while the crossing over the northern of the two channels of the run was characterized as the "Arch Bridge by ye m(ine).” The recently established King (later Neilson) Street between Albany and Water Streets and "Halfpenny’s House” were also depicted. Interestingly, even as late as 1797, a oneseventh share "in the New Brunswick Copper-mines, with a seventh part of all the buildings, improvements, utensils and lands thereto belonging, situate on Rariton river, and held by lease of Phillip French,” was still being offered for sale in $1797 .{ }^{53}$

James Parker died in Perth Amboy in 1797, and his will, drawn up earlier that same year,

\footnotetext{
${ }^{51}$ Morse, The American Geography; or, A View of the Present Situation of the United States of America, 290.

${ }^{52}$ Gordon, Gazetteer of the State of New Jersey, 11.

53 Pennsylvania Gazette, 15 February, 1797 (www.accessible.com/accessible/about/ aboutPG.jsp). This appears to have been derived from shares formerly held by Anthony Morris and John Reynolds.
} 


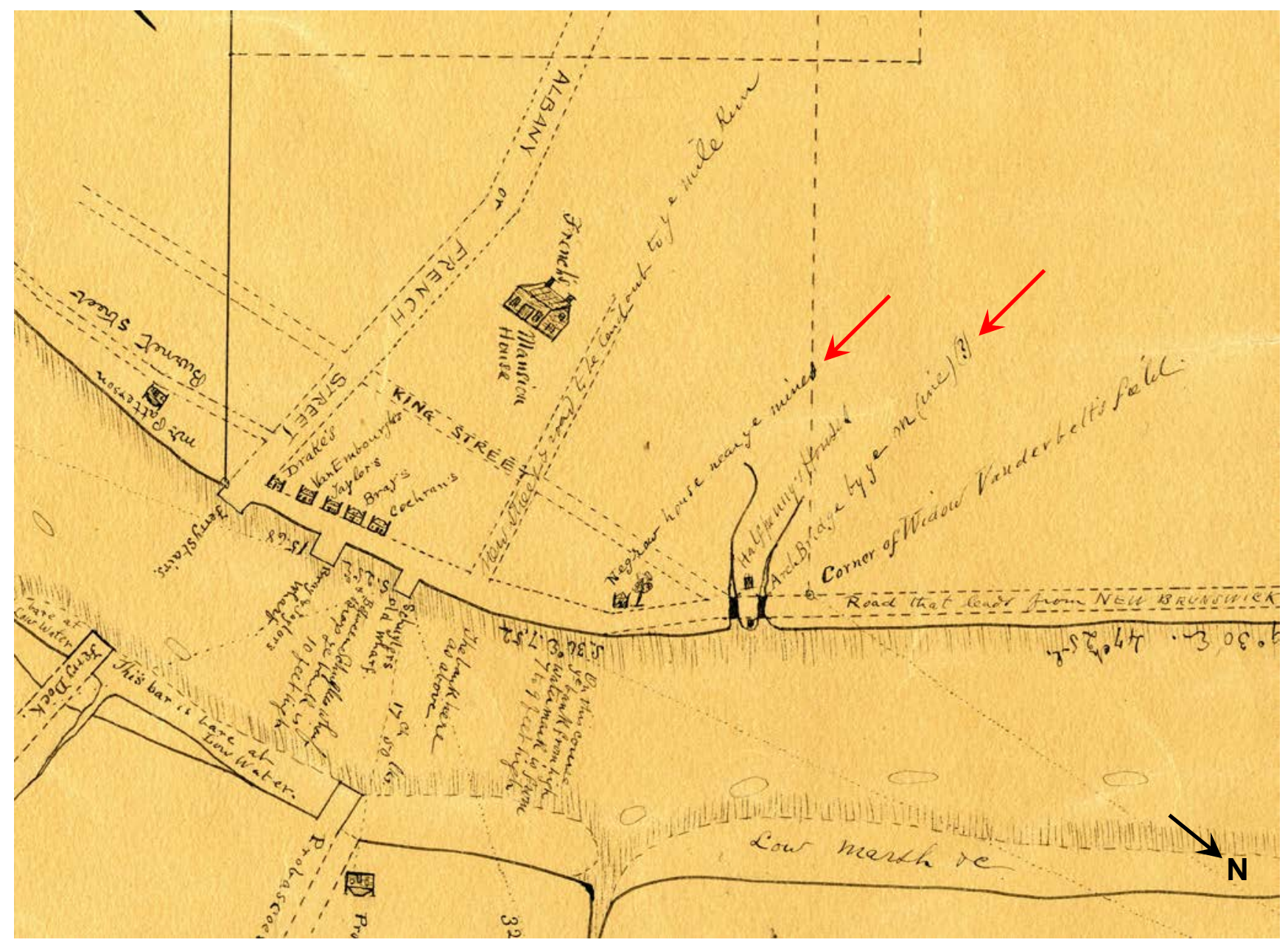

Figure 6. Map showing the "Negroes house near ye mines" and the "Arch Bridge by ye m(ine)" (arrows). Source: Benj. H. Manning, "Map of Land late of Mr. Phillip French late of New Brunswick deceased....,” 1790. (Manuscript Map \#20,015, Special Collections and University Archives, Rutgers University Libraries).

left his considerable real estate holdings to his various heirs. ${ }^{54}$ It was during the tenure of the Parker heirs that the lands formerly occupied by the copper mining and processing complex began to slowly develop as part of the growing City of New Brunswick. During the first quarter of the 19th century the city's street pattern was significantly expanded into the area to the north of Albany Street, beginning in 1808 with the opening of the present Hamilton Street/Johnson Drive between the New Jersey Turnpike (Easton Avenue) and the river. Both College Street

\footnotetext{
${ }^{54}$ New Jersey Wills (New Jersey State Archives), 8993L.
} 
(now College Avenue) and George Street were extended north to Hamilton Street at the same time. ${ }^{55}$ In 1811 College Street was extended to run north of Hamilton Street through the lands owned by the Parker heirs to reach the River Road. ${ }^{56}$ In 1824 George Street was extended north of Hamilton Street to cross Mine Run via a new stone bridge and continue on to connect with the River Road just above of the "half penny Town Stone bridge" over the run. ${ }^{57}$

Further change came slowly, however, and narrative accounts describing New Brunswick as it had been circa 1825 noted that the area to the north of the city was then still known as "The Mines.” A group of small dwellings sited in this area was commonly referred to as "The Mines,” “Ha’penny Town,” or “Arabtown,” and these houses were said to be largely occupied by those making their livings from the nearby river as fisherman and boatman. These working-class families, including members of the Halfpenny family, the original "settlers" here, were of both European and African-American descent, and they were generally characterized as either tenants or squatters on these lands. It was stated that the area was called "The Mines" as a result of the former copper mining activities here, and that evidence of those former activities could still be seen, including the spring marking the end of the former tunnel within the Mine Run gully. In 1834 it was noted that a "shaft of great depth is yet visible" in this area. ${ }^{58}$

It was the completion of the Delaware and Raritan Canal in 1834 that accelerated the pace of development within the area to the north of Albany Street. The canal, which had its

\footnotetext{
55 Somerset County Road Returns, Book B, 2. See also Titsworth, "Map of Land Betwen College Avenue and the Canal” and Wall, "History of the Streets of New Brunswick," 7.

${ }^{56}$ Somerset County Road Returns, Book B, 38. See also Titsworth, "Map of Land Betwen College Avenue and the Canal.” College Avenue was slightly altered to assume its present course between Hamilton and George Streets in 1834; see Somerset County Road Returns, Book B, 230.

${ }^{57}$ Somerset County Road Returns, Book B, 127.

${ }^{58}$ Gordon, Gazetteer of the State of New Jersey, 11; Charles D. Deshler, “A Walk About New Brunswick, Sixty Years Ago: 1825 - 1826” (manuscript, Rutgers University Libraries Special Collections and University Archives, 1886); and Charles D. Deshler, “The Vanished Things of My Day” (manuscript, Rutgers University Libraries Special Collections and University Archives, n.d.).
} 
eastern terminus at New Brunswick, was built along the south and west banks of the Raritan, construction required that several portions of the River Road be relocated to make way for the and new waterway. ${ }^{59}$ In addition, the segments of Water Street between Hamilton and George Streets and Neilson Street between Hamilton and Water Streets were formally vacated in 1836. The canal and its "Upper Lock” had been built on the site of this former segment of Water Street, while the course of the vacated segment of Neilson Street was utilized as the site of what was referred to as the "Water Power," a branch of the canal that was intended to provide hydropower potential in order to promote industrial development in the vicinity of the Upper Lock. Neilson Street was relaid to angle northwest from Hamilton street and connect with George Street just below the stone bridge over Mine Run. ${ }^{60}$

With the construction of the canal the lands whereon the New Brunswick Copper Mining and Processing Complex had formerly been sited were sold by the Parker estate to a partnership consisting of James Neilson and James C. Van Dyke of New Brunswick and Robert F. Stockton of Princeton, all leading figures in the financing and operation of the Delaware and Raritan Canal Company. ${ }^{61}$ The "Water Power" noted above was actually built by the New Brunswick Water Power Company, which included Neilson, Van Dyke, and Stockton among its incorporators and was essentially a subsidiary of the canal company. This new company anticipated generating revenues through the sale of potential mill properties adjacent to and the water rights associated

\footnotetext{
${ }^{59}$ It was noted in 1834 that portions of the old River Road had recently been relaid to run along the bank of the newly constructed canal; see Somerset County Road Returns, Book B, 230. See also Titsworth, "Map of Land Betwen College Avenue and the Canal." See William J. McKelvey, The Delaware \& Raritan Canal: A Pictorial History (York, Pa.: Canal Press, 1975); William J. McKelvey, Champlain to Chesapeake: A Canal Era Pictorial Cruise (Exton, Pa.: Canal Press, 1978); and David Gibson and Steven Bauer, "Delaware and Raritan Canal State Park: Historic Structures Survey” (report, New Jersey Historic Preservation Office, 1982) for information relative to the Delaware and Raritan Canal.

${ }^{60}$ Somerset County Road Returns, Book B, 278. See also Titsworth, "Map of Land Betwen College Avenue and the Canal.”

${ }^{61}$ See Somerset County Deeds, Book P, 514 and Book S, 384.
} 
with the new water power canal. Water was provided to the power canal by both the main canal and by Mine Run, which was reconfigured to drain directly into the power canal. Neilson built a saw mill at the head of the power canal and joined with Stockton to construct a four-story brick cotton factory on the north side of Hamilton Street. ${ }^{62}$

In 1836 the recently established New Jersey Geological Survey issued its first publication. This report mentioned the former mining activities at New Brunswick, but offered the opinion that the "metallic riches" of this and other of the state's copper mines had been much exaggerated. It was concluded that no actual vein of copper ore had ever been identified in the state, and that this assured that no significant profit had been or would be gained from the mining of copper in New Jersey. ${ }^{63}$ In 1839 a more detailed geological analysis of the copper deposits in the New Brunswick area was published by Lewis C. Beck, a geology professor at Rutgers College. Beck, while noting the former mining activities that had been carried on in New Brunswick during the colonial period, also concluded that these deposits, and those located elsewhere in the state, were not large enough to provide any promise of profitable mining operations. ${ }^{64}$

By 1845 full control of the former copper mining and processing complex property had passed to James Neilson and Robert F. Stockton. ${ }^{65}$ By mid-century this section of the City of

\footnotetext{
${ }^{62}$ A Directory of the City of New-Brunswick, for 1855, 22-3; New Brunswick and Its Industries, 13; Asher Atkinson, "Map of Property of Johnson and Johnson" (manuscript map, Rutgers University Libraries Special Collections and University Archives, 1893); Asher Atkinson, "Map of Property of Norfolk and New Brunswick Hosiery Co." (manuscript map, Rutgers University Libraries Special Collections and University Archives, 1894); "The Mines of New Brunswick"; and Wall, The Chronicles of New Brunswick, 311, 318.

${ }^{63}$ Henry D. Rogers, Report on the Geological Survey of the State of New Jersey (Philadelphia: Desilver, Thomas \& Co., 1836), 166-7.

${ }^{64}$ Lewis C. Beck, "Notices of the Native Copper, Ores of Copper, and other Minerals found in the vicinity of New Brunswick, New Jersey,” The American Journal of Science and Arts 36 (July 1839): 107-114. See also Lewis C. Beck, “Autobiographical narrative (covering 1819-50)” (manuscript, Rutgers University Libraries Special Collections and University Archives, 1851, microfilm) and Cook, Geology of New Jersey, 218-23.

${ }^{65}$ See Somerset County Deeds, Book V, 523 and 527, and Book B2, 561.
} 
New Brunswick had changed significantly, with much of that change, as noted above, having been precipitated by the construction of the canal along the south bank of the river (Figure 7). Water Street now ended at Hamilton Street, while Neilson Street now ran northwest to connect with George Street just below the still extant Mine Run, with the "Spring" shown on the run just to the east of College Avenue marking the outlet of the old tunnel from Mile Run. Neilson's Saw Mill was shown at the head of the power canal adjacent to the Upper Lock, while the Neilson and Stockton Cotton Factory stood just to the south on the north side of Hamilton Street. It was the foundation of this latter structure that Cook claimed was sited several feet out into the street to allow that a former mine shaft could be avoided, and the southern end of this building was shown to extend several feet to the south of the street's northern line. ${ }^{66}$

Industrial development in the area adjacent to the power canal continued with the construction of a rubber factory (later to become the Novelty Rubber Company) to the north of the cotton factory in $1853 .{ }^{67}$ In the following year James Neilson gained full control of all of the lands in New Brunswick that he had held jointly with Robert F. Stockton. Of particular interest among the numerous properties involved in this transaction was a 5.83-acre parcel that included a portion of the former copper mining and processing complex (including the site of the stamping mill). It was stated in the deed's description of this property that it was still subject to a lease given by Philip French to an unnamed person - possibly a very interesting reference to the two French-Koster leases concluded nearly a century earlier. ${ }^{68}$

The development of the lands formerly occupied by the New Brunswick Copper Mining

\footnotetext{
${ }^{66}$ See also J.C. Sidney, Map of the City of New-Brunswick (Philadelphia: Richard Clark, 1850) and "Map showing Mine Run between College Avenue and George Street” (manuscript map, Rutgers University Libraries Special Collections and University Archives, circa 1850).

${ }^{67}$ New Brunswick and Its Industries, 55-7; Clayton, History of Union and Middlesex Counties, 664-5; and Wall, The Chronicles of New Brunswick, 311, 318.

${ }^{68}$ Middlesex County Deeds (Middlesex County Court House), Book 64, 479.
} 


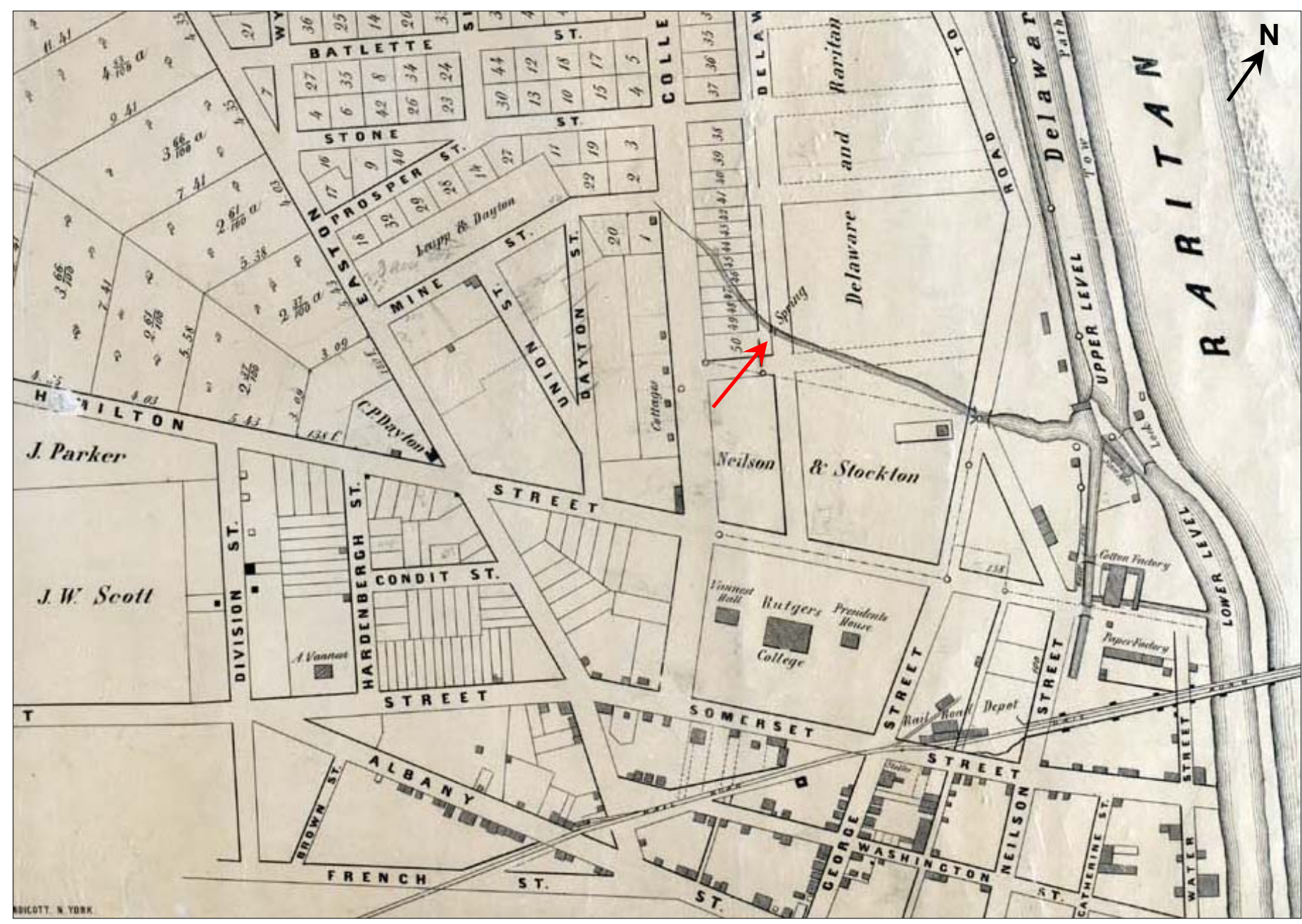

Figure 7. The "Spring" shown on Mine Run marks the former outlet of the tunnel from Mile Run that served the New Brunswick Copper Mining and Processing Complex.

Source: James H. Newell, Map of Part of the City of New Brunswick (New York: C. \& W. Endicott, 1847).

and Processing Complex accelerated significantly during the tenure of James Neilson and his heirs, which lasted into the early years of the $20^{\text {th }}$ century. Neilson donated the land upon which the independent campus for the New Brunswick Theological Seminary was developed in $1856 .{ }^{69}$ It was also at this time that Seminary Place was opened up between College Avenue and George Street, and that Mine Street, with the name referencing the former mining activities, was laid out

${ }^{69}$ Clayton, History of Union and Middlesex Counties, 689 and Richard P. McCormick, Rutgers: A Bicentennial History (New Brunswick, N.J., 1964), 74, 76. 


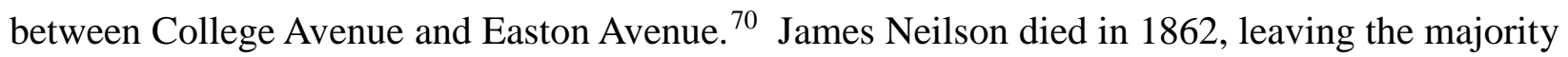
of his estate to his widow Catherine Bleecker Neilson and providing that after her death it would pass their son James Neilson $\mathrm{Jr}^{71}$ The development of the former mining and processing complex property was continued during the tenures of Neilson's widow and son as industrial and residential expansion and the growth of Rutgers College assured that the lands to the north of the city's core would be in high demand.

Industrial development along the power canal continued as the newly established Norfolk and New Brunswick Hosiery Company purchased the former Neilson and Stockton Cotton Factory in 1863. By 1873 this company, which included James Neilson Jr. on its Board of Directors, had become the largest manufacturer of hosiery goods in the United States. The company's factory complex on the power canal expanded considerably during the next several decades, but the four-story brick former Neilson and Stockton Cotton Factory building on Hamilton Street remained in use. ${ }^{72}$ As noted above, $19^{\text {th }}$ century sources outlining the history of the mining and processing complex claimed that former mine shafts were located at or near the northeast and southeast corners of this building.

During the decades following the Civil War the Neilson family sought to promote residential development within the area bounded by the canal and power canal, Seminary Place, College Avenue, and Hamilton Street. A number of dwellings, primarily worker's housing for those employed in the nearby factories, were built along the angled Neilson Street, the north side

\footnotetext{
${ }^{70}$ See the New Brunswick plan on Henry F. Walling, Map of Middlesex County (New York: Smith, Gallup and Company, 1861) and M. Hughes, Map of New Brunswick (Philadelphia: M. Hughes, 1866).

${ }^{71}$ Middlesex County Wills (Middlesex County Court House), Book G, 69.

${ }^{72}$ New Brunswick and Its Industries, 38-40; O.H. Bailey, Bird's Eye View of New Brunswick (Philadelphia: Fowler \& Bailey, 1874); Everts \& Stewart, "New Brunswick City - Sixth Ward," Atlas Map of Middlesex County (Philadelphia: Everts \& Stewart, 1875); Clayton, History of Union and Middlesex Counties, 659-60; Sanborn Map and Publishing Company, New Brunswick (New York: 1886); Sanborn-Perris Map Company, New Brunswick (New York: 1892); Sanborn-Perris Map Company, Insurance Maps of New Brunswick (New York: 1897); Sanborn Map Company, Insurance Maps of New Brunswick (New York: 1904); and Wall, The Chronicles of New Brunswick, 318.
} 
of Hamilton Street, and the east side of George Street. Further to the west Bleecker Place, named for the family of Catherine Bleecker Neilson, was opened up to run between Hamilton Street and Seminary Place circa 1870. This new street consisted of two parallel segments of roadway and sidewalk separated by a grass median, and it was expected to promote a more "exclusive" form of development by providing frontage for house lots sited along a pleasant street incorporating elements of open space. Although the pace of development in this area was somewhat slower, there were soon several larger dwellings in place here (including the above mentioned Doolittle House at 18 Seminary Place) that joined the previously constructed Neilson House (502 George Street) and Cook/Demarest House (542 George Street). Bleecker Place was initially sited on a raised embankment of fill that passed across the channel of Mine Run. Shortly thereafter, however, that the entire section of the run between College Avenue and George Street was placed within a culvert and filled to provide additional land appropriate for planned home sites. ${ }^{73}$

In 1886 George H. Cook described the condition and appearance of a number of features formerly associated with the long-abandoned New Brunswick Copper Mining and Processing Complex. He noted that the former tunnel's ventilation shafts (the former "mine holes") and the associated piles of rock spoil that had been removed during the tunnel's excavation were no longer visible on the ground surface. He added that the dam on Mile Run had recently been destroyed, and that the tunnel's intake was now readily apparent in the east bank of the run as a consequence of the drop in water level that resulted from the draining of the pond formerly retained by the dam. He also noted that during recent clearing activities in the vicinity of the

\footnotetext{
73 "Profile of Bleecker Place” (manuscript map, Rutgers University Libraries Special Collections and University Archives, n.d.); Bailey, Bird's Eye View of New Brunswick, 1874; Everts \& Stewart, "New Brunswick City - Sixth Ward” 1875; Sanborn Map and Publishing Company, New Brunswick, 1886; Sanborn-Perris Map Company, New Brunswick , 1892; and Wall, "History of the Streets of New Brunswick," 8. Mine Run continued to flow within its natural channel east from George Street to its outlet in the power canal until the turn of the century.
} 
intake several tools apparently utilized in the excavation of the tunnel had been recovered by the landowner and donated to the Rutgers College Geology Museum. Cook also related that the tunnel's former outlet (the "Boiling Spring”) was no longer visible as a consequence of the filling of Mine Run. ${ }^{74}$

It was Rutgers College, one of George H. Cook’s employers, that would have the most profound effect on the development of the block bounded by George Street, Seminary Place, College Avenue, and Hamilton Street. In 1888 the Neilson interests donated a lot on the north side of Hamilton to the college, and the following year saw the completion of the building still known today as New Jersey Hall. ${ }^{75}$ Rutgers next acquired a lot at the northwest corner of George and Hamilton Streets from the Neilson estate, and in 1894 it was reported that certain unidentified underground workings had been encountered during the excavation of the foundation for the new Ballantine Gymnasium. It was noted that similar features were also said to have been discovered during this period within sewer line excavations made along George Street and at the intersection of Hamilton and Neilson Streets, and it seems clear that these various underground features were surviving remnants of the mining operations that had formerly been sited here. ${ }^{76}$

\footnotetext{
${ }^{74}$ Cook, "The New Brunswick Copper Mines.” Cook also noted that James Parker Jr. of Perth Amboy had informed him that he had possession of the papers of the Brunswick Copper Mine Company, but that an examination of Parker's holdings had failed to produce any documentation specifically related to mine workings. As noted above, Cook lived very close to the former workings in the Cook/Demarest House, and this certainly contributed to his interest in the subject. See Wall, The Chronicles of New Brunswick, 327 for a picture of the "Entrance to the Tunnel at the Mile Run Brook" which shows an opening with a squared top in the bank and a large rock blocking access. ${ }^{75}$ Sanborn Map and Publishing Company, New Brunswick, 1886; McCormick, Rutgers: A Bicentennial History; Michael C. Barr, "New Jersey Hall” (National Register of Historic Places Nomination form, New Jersey Historic Preservation Office, 1974); and Michael Moffat, The Rutgers Picture Book: An Illustrated History of Student Life in the Changing College and University (New Brunswick: Rutgers University Press, N.J., 1985). New Jersey Hall, which now houses the Rutgers University Department of Economics, is listed on the New Jersey and National Registers of Historic Places.

${ }^{76}$ Hindes, “New Brunswick’s Famed Copper Mine Definitely Located by Charles Deshler.” Ballantine Gymnasium served as the school's center of sports and physical education until the building was severely damaged by fire in 1931. It was then replaced by the present College Avenue Gymnasium, with the surviving rear section of the building reconstructed as Ballantine Hall, which housed classrooms and offices. The building was subsequently
} 
Catherine Bleecker Neilson died in 1894, leaving her son James Neilson Jr. as the sole owner of the family's still extensive New Brunswick holdings. ${ }^{77}$ During the next several years Neilson sold all of the former copper mining and processing complex property sited to the east of George Street to Johnson \& Johnson. ${ }^{78}$ This new company had been established in New Brunswick in 1886 and had acquired and occupied the former Novelty Rubber Company factory on the water power canal shortly thereafter. Johnson \& Johnson continued its growth as a manufacturer of medical and pharmaceutical products during the next several years, and the acquisitions from Neilson were completed to allow for the expansion of their facility. By the turn of the century Johnson \& Johnson fully controlled the area bounded by the canal and the power canal, George Street, and Hamilton Street. By 1904 the last remaining segment of Mine Run had been placed within a buried culvert, and the angled section of Neilson Street north of Hamilton had been vacated. During the next several decades this entire area was completely redeveloped, with the working class residential buildings formerly sited here replaced by a complex of large brick industrial buildings. Included among these was a large multi-component building sited on the north side of Hamilton Street about midway between the power canal and George Street that would come to be known as Kilmer House. ${ }^{79}$

\footnotetext{
incorporated as part of the present Zimmerli Art Museum, which opened in 1983 - see Sanborn-Perris Map Company, Insurance Maps of New Brunswick, 1897; Sanborn Map Company, Insurance Maps of New Brunswick, 1904; Sanborn Map Company, Insurance Maps of the City of New Brunswick (New York: 1912); Sanborn Map Company, Insurance Maps of the City of New Brunswick (New York: 1912, corrected to 1950); McCormick, Rutgers: A Bicentennial History; and Moffat, The Rutgers Picture Book.

${ }^{77}$ Middlesex County Wills, Book O, 777.

${ }^{78}$ Middlesex County Deeds, Book 283, 148, Book 314 141, and Book 336519.

79 “Delaware and Raritan Canal Right-of-Way Map,” (manuscript map, New Jersey State Archives, 1901); Sanborn Map Company, Insurance Maps of New Brunswick, 1904; Sanborn Map Company, Insurance Maps of the City of New Brunswick, 1912; Sanborn Map Company, Insurance Maps of the City of New Brunswick, 1912, corrected to 1950. By 1912 Johnson \& Johnson had also acquired the former Norfolk and New Brunswick Hosiery Company facility, including the old Neilson and Stockton Cotton Factory building. See also Meredith Arms Bzdak and Richard L. Porter, "Historical and Architectural Study: Kilmer House, Johnson \& Johnson Corporate Headquarters, City of New Brunswick, Middlesex County, New Jersey” (report, Rutgers University Libraries Special Collections and University Archives, 1993). The first sections of Kilmer House were built in 1896, with the last section of the building completed in 1941.
} 
The development activities of Rutgers College to the west of the expanding Johnson \& Johnson complex also continued during the early decades of the $20^{\text {th }}$ century. Voorhees Hall was completed in 1903 on a lot acquired from James Neilson Jr. (who was, in fact, a graduate of Rutgers College) and served as the institution's library for a number of years. In 1906 Neilson donated all of his remaining landholdings in the area between George Street, Seminary Place, College Avenue, and Hamilton Street to the college with the request that this area be known as Neilson Campus in honor of his father, and five important educational buildings were built here during the next quarter century (Figure 8). All five of these buildings - Murray Hall (1909), Milledoler Hall (1910), Ford Hall (1914), the Ceramics Building (1922), and Van Dyck Hall (1928) - were sited in close proximity to the central core of the former mining and processing complex, with several - from east to west, the Ceramics Building, Milledoler, Van Dyck, and Ford - sited directly over the former course of Mine Run. The remains of the former tunnel are said to have been encountered during the construction of Ford Hall, and Murray and Milledoler Halls and the Ceramics Building are clustered in the area likely to have been the site of the former processing center. ${ }^{80}$ During the excavations for the foundations of Van Dyck Hall “wooden uprights and abandoned choked-up passages” were encountered that caused delays lasting several months as the foundation was redesigned to provide for the necessary support of the building. The siting of Van Dyck at or near the site of the former outlet of the tunnel suggests

\footnotetext{
${ }^{80}$ Sanborn Map Company, Insurance Maps of New Brunswick, 1904; Sanborn Map Company, Insurance Maps of the City of New Brunswick, 1912; Sanborn Map Company, Insurance Maps of the City of New Brunswick, 1912, corrected to 1950; McCormick, Rutgers: A Bicentennial History, Moffat, The Rutgers Picture Book; and Fernanda Perrone, “Voorhees Hall: Rutgers’ First Modern Library,” Journal of Rutgers University Libraries 61 (2005). Voorhees Hall, like the adjacent Ballantine Hall, was later incorporated as part of the Zimmerli Art Museum and now houses the Department of Art History. The current uses of the other buildings constructed during this period are as follows: Murray Hall - English Department; Milledoler Hall - administrative offices; Ford Hall - residential space; Ceramics Building - School of Social Work; and Van Dyck Hall - History Department. Bleecker Place, which ran down the center of the block, was vacated, although its former right-of-way retains its original open space concept as the shaded mall dividing Voorhees Mall into eastern and western halves. The block was, indeed, known as the Neilson Campus until 1974 - the present name honors prominent Rutgers figure Tracy S. Voorhees.
} 


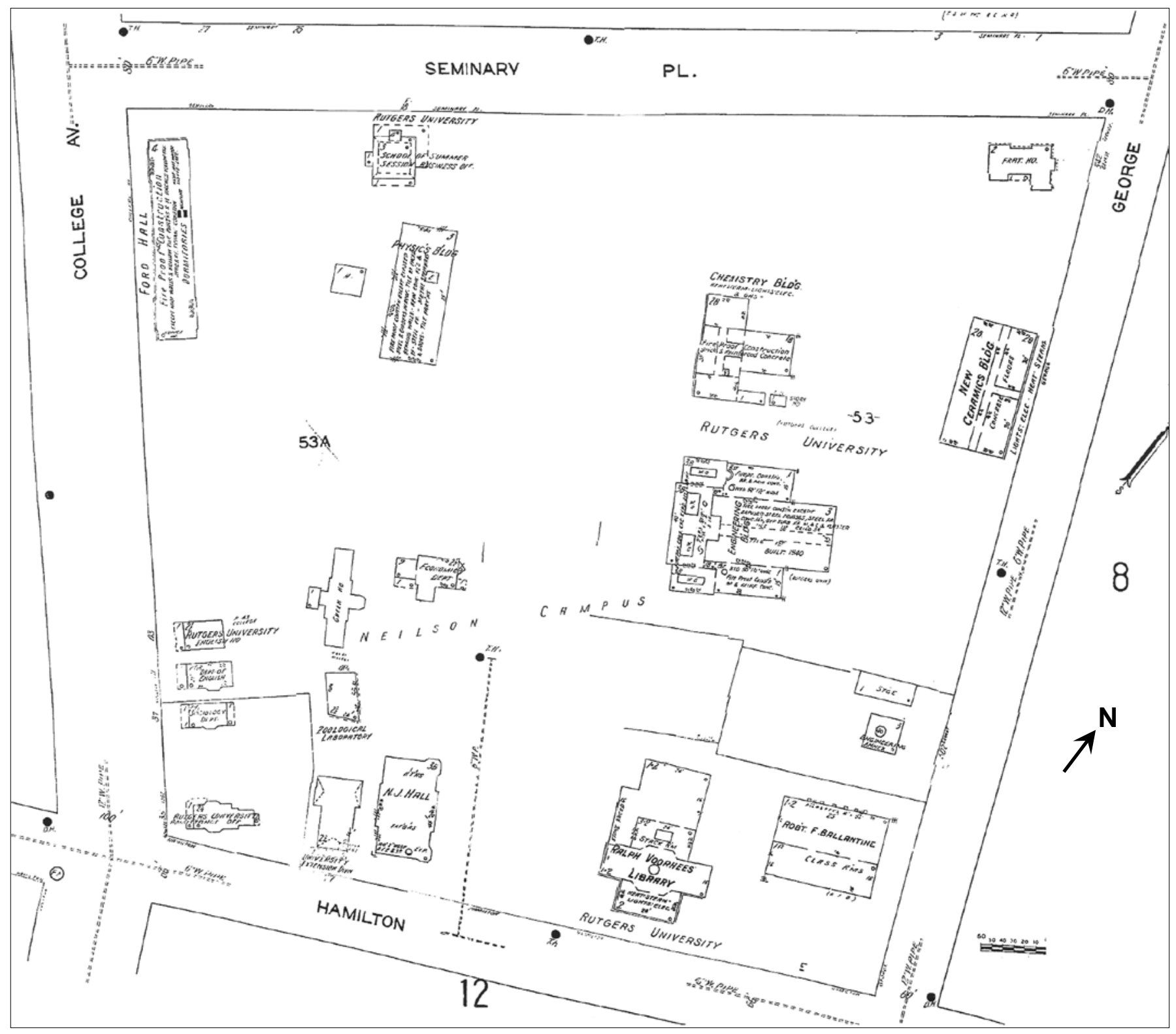

Figure 8. The Neilson Campus (now the Voorhees Mall) of Rutgers University in 1950, showing the Ceramics Building, Milledoler Hall (“Chemistry Bldg”), Murray Hall (“Engineering Bldg”), Van Dyck Hall ("Physics Bldg”), and Ford Hall. Source: Sanborn Map Company, Insurance Maps of the City of New Brunswick (New York: 1912, corrected to 1950). 
that these features were associated with its far eastern end. ${ }^{81}$

By mid-century the eastern section of the former New Brunswick Copper Mining and Processing Complex was fully developed as the core of the massive Johnson \& Johnson facility. The former Neilson and Stockton Cotton Factory building, said to be sited near two former mine shafts, still stood on the north side of Hamilton Street just to the east of the now abandoned water power canal. ${ }^{82}$ Kilmer House, sited just to the west and utilized primarily for offices and shipping and receiving, had reached its final form, with the last portion of this series of connected buildings having been completed in 1941 a short distance to the north of Hamilton Street (Figure 9).

Kilmer House was demolished during the summer of 1993 as it had been determined to be antiquated space unsuitable for renovation. During the initial stages of this demolition project a water-filled void extending vertically into the Brunswick shale bedrock was encountered within the section of Kilmer House that was built in 1941. This void measured 10 feet by 16 feet in plan and approximately 25 feet in depth to the surface of the ground water contained within it. Documentary research conducted by Rutgers University personnel at the request of Johnson \& Johnson led rapidly to the conclusion that the proximity of this feature to other elements of the former New Brunswick Copper Mining and Processing Complex dictated that it was a former mine shaft excavated during the first two decades of the second half of the 18th century.

The Kilmer House Shaft was dewatered on several occasions during the summer of 1993 and examined both visually and through the use of a suspended video camera. As noted above,

\footnotetext{
${ }^{81}$ Rutgers University Building Records (Rutgers University Office of Facilities Design); “Deposits of Copper Found on Site of Wessels Dorm Believed To Be Part of Mine of Revolutionary Times,” The Targum, 26 November, 1929 ; “Large Quantities of Copper Ore Uncovered by Steam Shovel Doing Excavating on Rutgers Campus,” The Daily Home News, 4 December, 1929; and Hindes, "New Brunswick’s Famed Copper Mine Definitely Located by Charles Deshler.”

${ }^{82}$ Sanborn Map Company, Insurance Maps of the City of New Brunswick, 1912, corrected to 1950. The former Neilson and Stockton Cotton Factory building was demolished during the 1960s.
} 


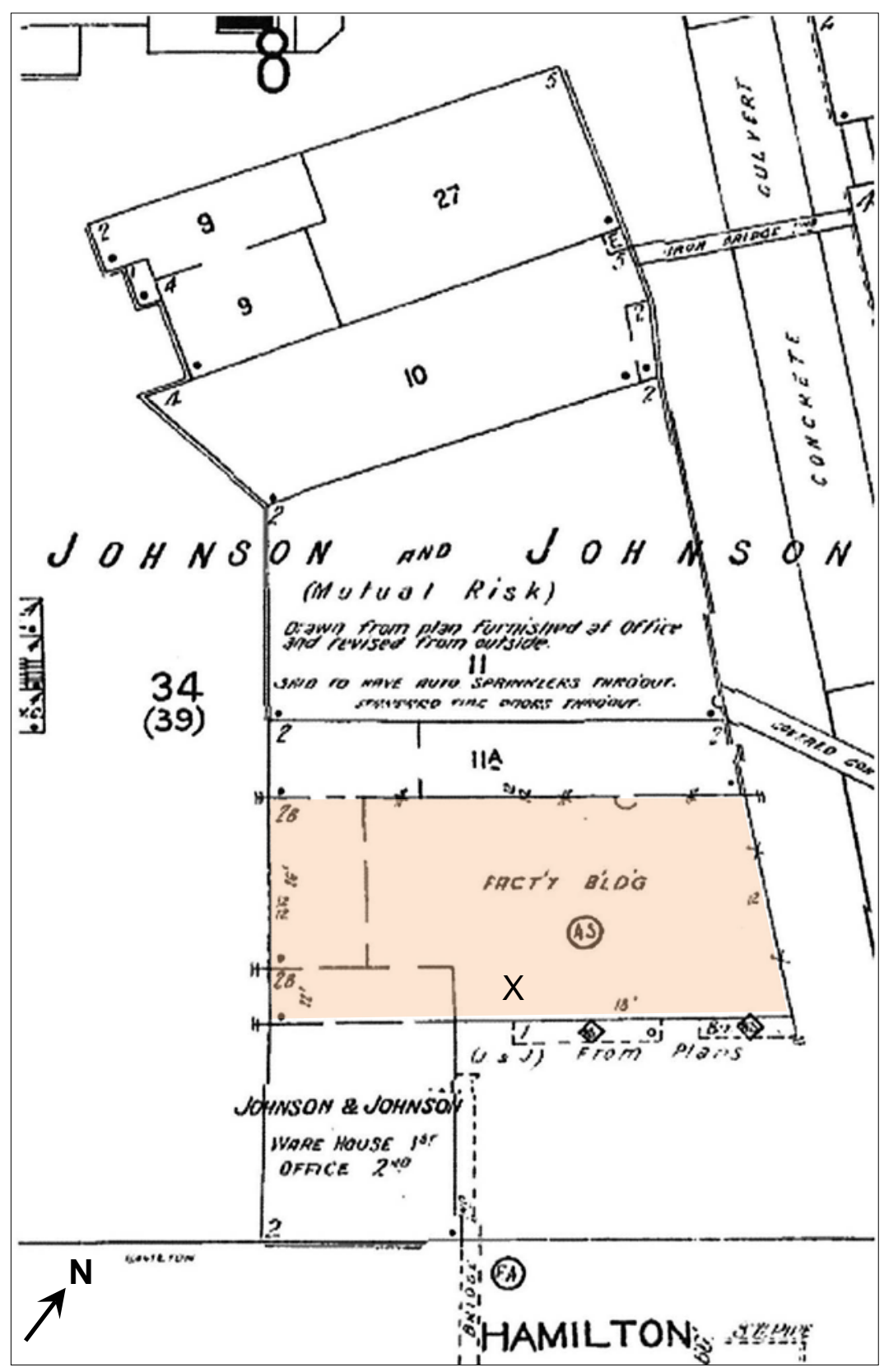

Figure 9. The Johnson \& Johnson Kilmer House in 1950 - the section of the building completed in 1941 is shaded, with location of shaft encountered in 1993 indicated (X).

Source: Sanborn Map Company, Insurance Maps of the City of New Brunswick (New York: 1912, corrected to 1950). 
the shaft measured 10 feet by 16 feet in plan, and it was found to extend to a total depth of approximately 70 feet (Figure 10). The concrete floor of the section of Kilmer House built in 1941 had served additionally as the capping mechanism for the shaft, with the remnants of an earlier concrete cap visible several feet below the ground surface. The upper section of the shaft was defined by unconsolidated fill in the south, west, and north walls that extended to a depth of approximately 10 feet below the surface. The east wall of the upper section of the shaft was formed by an interior foundation wall for the 1941 building.

The shaft was excavated through the Brunswick shale bedrock for the remainder of its depth of approximately 70 feet. The surviving remnants of three tiers of hewn timber shoring were visible at the 40-foot, 47-foot, and 54-foot (all approximate) levels. These remnants included the middle level timber in the east wall of the shaft, the lower level timber in the south wall, and all three timbers in the west wall. In addition, the notch that had been carved out of the bedrock to support the now missing east wall upper level timber was visible in the north wall. A horizontal passage, almost certainly a drift excavated to facilitate the removal of copper ore, was encountered within the east wall of the shaft at the 56-foot (approximate) level. This drift extended in a generally easterly direction (toward the Raritan River) for distance of at least 20 feet (this distance represented the full extent of the camera's view from its position in the shaft). The drift exhibited a roughly hewn timber roof at its point of contact with the shaft. This roof was constructed of supporting timbers laid perpendicularly across the top of the drift topped by roofing timbers running parallel to the length of the drift.

With the completion of the demolition of Kilmer House and the basic recordation of the Kilmer House Shaft, plans for the filling of the shaft were filed with and approved by the Mine Safety Bureau of the New Jersey Department of Labor's Office of Safety Compliance within the 


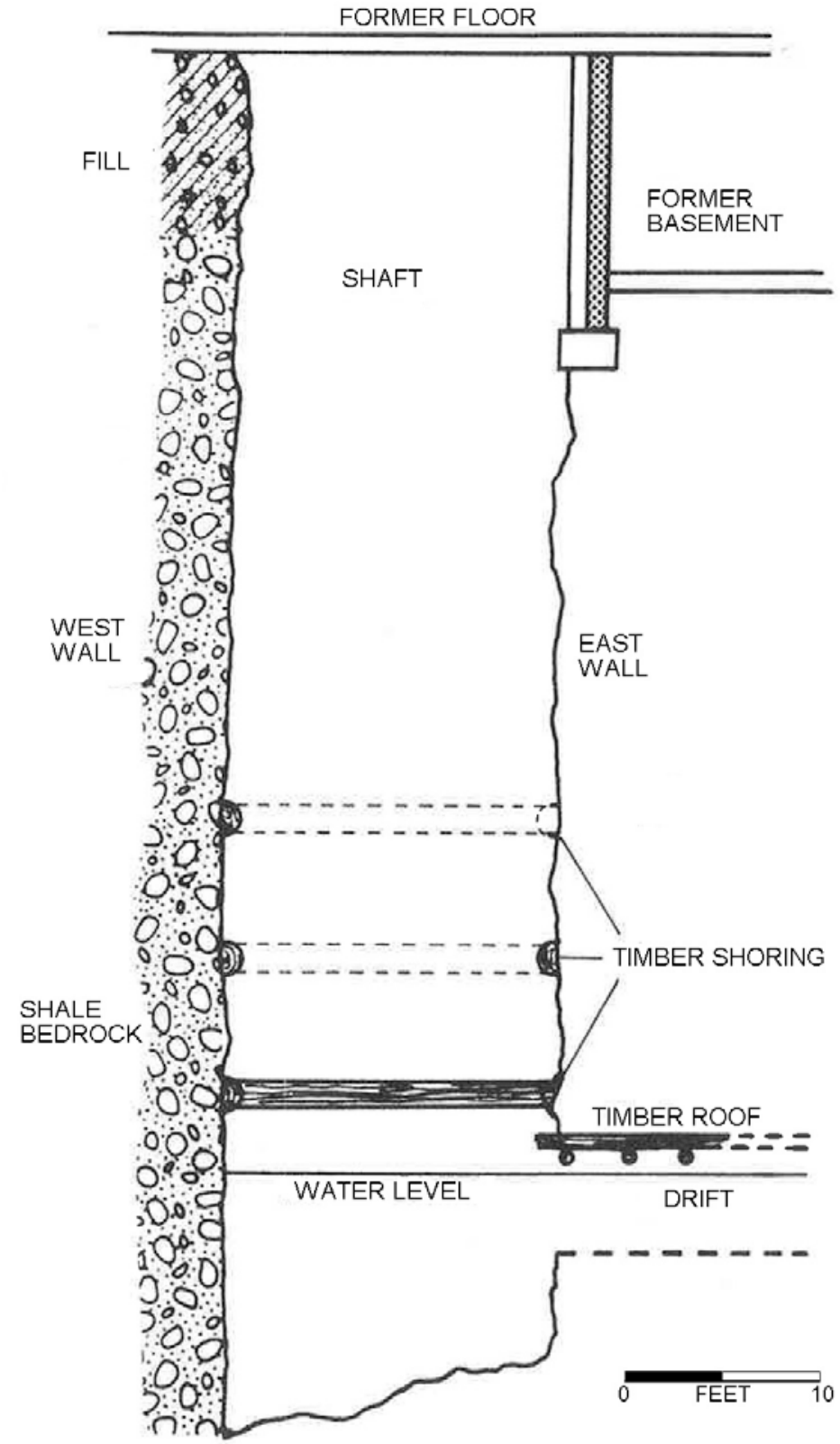

Figure 10. Cross Section through the Kilmer House Shaft.

Source: Richard L. Porter, "A History of the New Brunswick Copper Mining Complex, City of New Brunswick, Middlesex County, New Jersey,” 1993.

(Report, Special Collections and University Archives, Rutgers University Libraries). 
Division of Workplace Standards. The shaft was filled and sealed during the fall of 1993 to allow for the completion of the extensive lawn area developed on the former Kilmer House site. The survival of this feature of the New Brunswick Copper Mining and Processing Complex should serve as evidence of the possibility that additional archaeological remnants of this resource may survive elsewhere in the vicinity, despite the institutional, industrial, and residential development that brought change to the mid- $18^{\text {th }}$ century landscape. The most likely area of potential is, in fact, within the Voorhees Mall section of the College Avenue Campus of Rutgers University. The filling of the Mine Run gully, with filling activities often serving to protect archaeological remains, along with the several recorded encounters with such remains over the years speaks strongly to this suggestion as to the potential for the survival of significant historic archaeological resources in this location. The importance of the opportunity to professionally study any archaeological remnants of the New Brunswick Copper Mining and Processing Complex, a resource that would be of great significance as a unique example of a poorly understood colonial industry, should be readily apparent to all.

Richard L. Porter is the Supervisor/Historian of the Cultural Resource Unit within the Environmental Department of The RBA Group, an engineering and environmental consulting concern located in Parsippany and Ewing, NJ. He holds an undergraduate degree in History from Muhlenberg College and a master's degree in American History from Rutgers University. This article was written as a consequence of the interest shown in the topic by Richard P. McCormick and is dedicated to his memory. 